NBER WORKING PAPER SERIES

\begin{abstract}
THE NET ASSET POSITION OF THE
U.S. NATIONAL GOVERNMENT, 1784-1802:

HAMILTON'S BLESSING OR THE SPOILS OF WAR?
\end{abstract}

\author{
Farley Grubb \\ Working Paper 11868 \\ http://www.nber.org/papers/w11868 \\ NATIONAL BUREAU OF ECONOMIC RESEARCH \\ 1050 Massachusetts Avenue \\ Cambridge, MA 02138 \\ December 2005
}

The author is Professor of Economics, University of Delaware, Newark, DE 19716 USA, and Research Associate of the NBER. http://myprofile.cos.com/grubbf16; grubbf@lerner.udel.edu. A preliminary version was presented at the 65th annual meeting of the Economic History Association, Toronto, Canada, 2005. The author thanks these seminar participants, as well as Stacie Beck, Jim Butkiewicz, Eleanor Craig, Bill Latham, and Richard Sylla for helpful comments, and thanks Kimberley Fersch and Eric O'Connor for research assistance and Tracy M. Cass for editorial assistance. The views expressed herein are those of the author(s) and do not necessarily reflect the views of the National Bureau of Economic Research.

C2005 by Farley Grubb. All rights reserved. Short sections of text, not to exceed two paragraphs, may be quoted without explicit permission provided that full credit, including $(\odot)$ notice, is given to the source. 
The Net Asset Position of the U.S. National Government, 1784-1802: Hamilton's Blessing or the Spoils of War?

Farley Grubb

NBER Working Paper No. 11868

December 2005

JEL No. E62, F34, G18, H60, N41

\begin{abstract}
The War for Independence left the National Government deeply in debt. The spoils from winning that war also gave it an empire of land. So, post-1783, was the National Government solvent? Was its net asset position, land assets minus debt liabilities, positive or negative? Evidence is gathered to answer this question by constructing a yearly time series of its net asset position, including time series of the subcomponents of that position, from 1784 through 1802 . The answer to this question may help explain the constraints that determined why the National Debt was funded in the particular way that it was. The results from the data series constructed indicate that the National Government was solvent, had more than enough land assets to cover its debt liabilities, in this period but only if it maintained the default on the Continental Dollar (its non-interest-bearing debt). To do this and not ruin its creditworthiness it had to distinguish, legally and in the marketplace, between its interestbearing and its non-interest-bearing debt. It did this, in part, by only paying interest and no principal on its debts and by curtailing direct swaps of land for debt.

Farley Grubb

University of Delaware

Economics Department

Newark, DE 19716

and NBER

grubbf@lerner.udel.edu
\end{abstract}




\section{The Net Asset Position of the U.S. National Government, 1784-1802: Hamilton's Blessing or the Spoils of War?*}

The War for Independence left the National Government deeply in debt. The spoils from winning that war also gave it an empire of land. So, post-1783, was the National Government solvent? Was its net asset position, land assets minus debt liabilities, positive or negative? Evidence is gathered to answer this question by constructing a yearly time series of its net asset position, including time series of the subcomponents of that position, from 1784 through 1802. The answer to this question may help explain the constraints that determined why the National Debt was funded in the particular way that it was. (JEL E62 F34 G18 H60 N41)

"I know no subject that is So little understood or has been less profoundly examined by the legislative Characters of America, than that of Finance..." 1

\section{Introduction}

The U.S. National Government incurred significant debt during the War for Independence (1775-1783). By 1790 almost nothing had been paid on this debt. The National Government was in default and had been in default on the domestic portion of its debt for over a decade. In 1790, under the auspices of the new Constitution adopted by Congress in 1789, the National Government "un-defaulted" part of its domestic debt and also assumed responsibility for the remaining war debts of the individual states, but only after a fashion. ${ }^{2}$ It funded the interest payments due on these debts only-intending for the most part to pay nothing toward reducing the principal. In 1791 the face value of the funded principal of the National Government's debt totaled \$77 million (Spanish silver dollars). In 1802 the National Government was still \$77 million in debt.

Yet, by the mid-1790s the U.S. National Government - mired deeply in debt, with no intention of paying down the principal of this debt any time soon, having failed to undefault all its war debt, and having yet to garner a reputation for never missing an interest payment on the portion of the debt it had un-defaulted in 1790 - was still able somehow 
to garner an excellent credit rating in Europe. John Steele Gordon (1998, p. 39) observed that, "By 1794 it [the U.S. National Government] had the highest credit rating in Europe, and some of its bonds were selling at 10 percent over par. Talleyrand, who later became the French foreign minister, explained why. The United States bonds, he said, were 'safe and free from reverse. They have been funded in such a sound manner and the prosperity of this country is growing so rapidly that there can be no doubt of their solvency"”

How was this possible? Many scholars point to the plan for funding the National Debt proposed in January of 1790 by the Secretary of the Treasury, Alexander Hamilton, as the explanation. This plan, adopted by Congress in August of 1790 with only minor alterations, has even been called a financial revolution, a miracle and, by Hamilton, a “national blessing." (Syrett, 1962, v. 6, p. 106) How this plan instantly overcame all the negatives mentioned above to the National Government's credit record and why the plan took the exact shape it did has remained somewhat enigmatically, or at best incompletely, explained — being for some writers just what miracles are made of (Gordon, 1998).

The literature on the National Debt frequently forgets the asset side of the ledger. War can produce a mountain of debt, but the spoils from winning a war can also produced a treasure chest of assets. Between 1784 and 1802 the U.S. National Government acquired an empire of land—claims legally gained as the spoils of war in the Treaty of Paris that granted the U.S. independence. While initially the individual states claimed these lands based on old colonial grants and Indian treaties, one by one the states from 1781 through 1802 ceded their claims to the National Government. By 1802 the U.S. National Government had been ceded 222 million acres of land between the current borders of the original 13 states and the Mississippi River. The states considered that the 
lands they had ceded to the National Government were to be used for the common benefit of all U.S. citizens. In particular, the lands were to be used to payoff or provide the security that would back up the war debt incurred to gain independence.

So-did winning the War for Independence leave the U.S. National Government in a net positive or a net negative asset position? Were its land assets sufficient to cover or provide security for its debt liabilities? In other words, was the National Government solvent? If it was solvent, then its excellent credit rating may have had more to do with the spoils of war-land backed debt — than with Hamilton's funding plan. ${ }^{3}$ If it was insolvent, then maybe Hamilton and Congress really did work miracles in 1790.

The task here is to answer this question by estimating the net asset position of the U.S. National Government including its subcomponents in both real and nominal terms from 1784 through 1802. The starting point is determined by the Treaty of Paris (late 1783) that recognized the U.S. as an independent sovereign entity. Without sovereign recognition, the debts incurred and lands claimed prior to 1784 lacked legitimacy. The end point of 1802 was chosen because it was when the last of the lands granted under the Treaty of Paris and claimed by one the original 13 states (Georgia) was finally ceded to the U.S. National Government. Using 1802 as the end point also carries the estimate through the administrations of the "High Federalists" (Washington and Adams) covering the financial revolution most closely identified with Alexander Hamilton. In 1803 the Jefferson administration changed the net asset position of the nation with the Louisiana Purchase - complicating the calculation and altering the inferences that might be drawn.

By estimating the government's net asset position in this period new perspectives are gained on why the financial revolution took the exact shape that it did and on how the 
U.S. could have achieved an excellent credit rating in Europe despite being a new country with a new government and a checkered history of debt default. In particular, why did the U.S. National Government in 1790 chose to un-default its interest-bearing debt but not its non-interest bearing debt? Why did it or how could it un-default the interest-bearing debt at face value rather than at market value? How could it responsibly assume the remaining war debts of the states? Finally, why did it turn its interest-bearing debt into callable perpetuities - making full and regular interest payments but exempting itself from ever paying down the principal unless it so exercised its option to pay it down?

Before the net asset position is estimated and these questions answered, a model is developed to show that the government's asset position matters to its creditworthiness, and evidence is offered to show that contemporaries viewed land assets as backing the National Debt, i.e. viewed the public domain and the National Debt as inexorably linked.

\section{Do Government Assets Matter? A Budget Constraint Model of Creditworthiness}

The government's budget constraint connects its cash flows to its capital stocks. In particular, the government's yearly tax revenue $\left(\mathbf{T}_{\mathbf{i}}\right)$ minus its yearly expenditures $\left(\mathbf{G}_{\mathrm{i}}\right)$ must equal the change in its stock of net capital assets $\left(\mathbf{A}_{\mathbf{i}}-\mathbf{D}_{\mathbf{i}}\right)$, where $\mathbf{A}$ are salable capital assets - e.g. inventories of specie and land, and $\mathbf{D}$ are the face value of its debt liabilities - principally callable perpetuities with the principal payable only at the government's discretion and old fiat currency for the U.S. in this period. ${ }^{4}$

$$
\mathbf{T}_{\mathrm{i}}\left[\left(t^{*} \mathbf{I}_{\mathrm{i}}\right)+\mathbf{O}_{\mathrm{i}}\right]-\mathbf{G}_{\mathrm{i}}\left[\left(\left(1-k_{\mathrm{i}}\right)^{*} \mathbf{R}_{\mathrm{g}} * \mathbf{D}_{\mathrm{i}}\right)+\mathbf{E}_{\mathrm{i}}\right]=\Delta\left(\mathbf{A}_{\mathrm{i}}-\mathbf{D}_{\mathrm{i}}\right)
$$

For the U.S. National Government in this period the principal tax revenue came from a tariff $(t)$ on current imports $\left(\mathbf{I}_{\mathrm{i}}\right)$, with $\mathbf{O}_{\mathrm{i}}$ representing all other current-year tax revenues, such as from the whiskey tax. Yearly expenditures comprise the interest the 
National Government owes on the face value of its current stock of interest-bearing debt $\left(\mathbf{R}_{\mathrm{g}} * \mathbf{D}_{\mathrm{i}}\right)$ that it does not default on $\left(1-k_{\mathrm{i}}\right)$, where $k_{\mathrm{i}}$ is the default rate $\left(0 \leq k_{\mathrm{i}} \leq 1\right)$, with $\mathbf{E}_{\mathrm{i}}$ representing all other current-year expenditures, such as military expenditures.

When the government has a budget surplus $\left[\mathbf{T}_{\mathrm{i}}-\mathbf{G}_{\mathrm{i}}>0\right]$ it has excess revenue and, assuming that it is not in default on its interest payments (i.e. that $k_{\mathrm{i}}=0$ ), it must either increase its stock of assets $\left[\mathbf{A}_{\mathrm{i}+1}>\mathbf{A}_{\mathrm{i}}\right]$ and/or pay down and retire some of the principal on its debt $\left[\mathbf{D}_{\mathrm{i}+1}<\mathbf{D}_{\mathrm{i}}\right]$. When the government has a budget deficit $\left[\mathbf{T}_{\mathrm{i}}-\mathbf{G}_{\mathrm{i}}<0\right]$ then the shortfall in revenue must be covered either by selling some assets $\left[\mathbf{A}_{\mathrm{i}+1}<\mathbf{A}_{\mathrm{i}}\right]$ and/or borrowing more $\left[\mathbf{D}_{\mathrm{i}+1}>\mathbf{D}_{\mathrm{i}}\right]$ and/or increasing its default on its interest payments $\left(k_{\mathrm{i}+1}>k_{\mathrm{i}}\right)$. If an important goal of the government is to protect its creditworthiness by keeping $k_{\mathrm{i}}=0$, then increasing $k$ is not an option but a last resort. If the government has no assets (A) then it has to increase its debt liabilities (D). However, increasing $\mathbf{D}$ via interest-bearing liabilities raises $\mathbf{G}$ in the future $\left[\left(\mathbf{R}_{\mathrm{g}} * \mathbf{D}_{\mathrm{i}+1}\right)>\left(\mathbf{R}_{\mathrm{g}} * \mathbf{D}_{\mathrm{i}}\right)\right]$ which puts increased pressure on the budget to stay in deficit $\left[\mathbf{T}_{\mathrm{i}+1}-\mathbf{G}_{\mathrm{i}+1}<0\right]$ particularly given that in this period the U.S. National Government's ability to raise taxes in the near future was tightly constrained, i.e. it is likely that $\mathbf{T}_{\mathrm{i}+\mathrm{n}}=\mathbf{T}_{\mathrm{i}}$. This scenario puts the government in an unsustainable long-run position and so puts increasing pressure on the government to increase $k$, i.e. to default in the near future (Taylor, 1950, p. 5). It also puts the government in a position where the likelihood of it being able to pay down or retire any of the principal of $\mathbf{D}$ at face value in the near future is greatly reduced. This in turn makes potential lenders reluctant to contract with the government in the near future.

This last scenario fits the United States in the late 1780s as James Madison explained it to Thomas Jefferson on October 24, 1787, 
Such is the state \& prospect of our fiscal department that any new loan however small, that should now be made, would probably subject us to the reproach of premeditated deception. The balance of Mr. Adams' last loan will be wanted for the interest due in Holland, and with all the income here, will, it is feared, not save our credit in Europe from further wounds. It may well be doubted whether the present Govt. can be kept alive thro' the ensuing year, or untill the new one may take its place. (Rutland, 1977, v. 10, p. 218; Swanson, 1963, p. 36)

As such, the government's net asset position $\left(\mathbf{A}_{\mathrm{i}}-\mathbf{D}_{\mathrm{i}}\right)$ should be an important factor in assessing its creditworthiness. It represents a safety valve that could potentially relieve the pressure to default when the budget would unexpectedly fall into deficit, as well as provide a potential resource to draw on if the government's ability to pay off or retire $\mathbf{D}$ at face value became a concern to potential lenders. It is important to note that it is not the actual current revenue or contemporaneous cash flow from the sale of $\mathbf{A}$ that matters to assessing the government's creditworthiness but A's potential salability to cover or back the government's current and future debt position that matters.

The government's budget constraint can be transformed into a model of its creditworthiness. The government's relatively poor credit rating compared with the market is measured as the risk spread between the interest rate the government is charged $\left(\mathbf{R}_{\mathrm{g}}\right)$ and the rate in the marketplace on low risk loans $\left(\mathbf{R}_{\mathrm{m}}\right)$. This risk spread is a positive function of the government's reputation failure, i.e. its record of not paying interest on its debt - how close $k$ is to 1 -as a weighted average $(a)$ over the recent past; a negative function of the government's expected budget surpluses $\left(\operatorname{Ex}\left[\mathbf{T}_{\mathrm{i}+\mathrm{n}}-\mathbf{G}_{\mathrm{i}+\mathrm{n}}\right]\right)$; and a negative function of the government's net asset position $\left(\mathbf{A}_{\mathrm{i}}-\mathbf{D}_{\mathrm{i}}\right)$.

$$
\left(\mathbf{R}_{\mathrm{g}}-\mathbf{R}_{\mathrm{m}}\right)=\boldsymbol{f}\left[\left(\mathbf{A}_{\mathrm{i}}-\mathbf{D}_{\mathrm{i}}\right) ; \operatorname{Ex}\left(\mathbf{T}_{\mathrm{i}+\mathrm{n}}-\mathbf{G}_{\mathrm{i}+\mathrm{n}}\right) ;{ }_{\mathrm{i}=1} \sum^{\mathrm{i}-\mathrm{n}}\left(\boldsymbol{a}_{\mathrm{i}}^{*} \boldsymbol{k}_{\mathrm{i}}\right)\right]
$$

[Where ${ }_{\mathrm{i}=1} \sum^{\mathrm{i}-\mathrm{n}}\left(a_{\mathrm{i}}\right)=1 ;\left(\mathbf{R}_{\mathrm{g}}-\mathbf{R}_{\mathrm{m}} \geq 0\right)$; and $\mathrm{n}=$ a number of years looking into the future $(i+n)$ or into the past $(i-n)]$. 
Between 1781 and 1790 the U.S. National Government made next to no interest or principal payments on the domestic portion of its debt (Taylor, 1950, p. 2). In effect, $k=1$ over the recent past so that even when the government started paying interest in full $(k=0)$ after 1790, its reputation for paying the interest on its debt would not fully recover until well after 1790. Expected budget surpluses did not look promising even after 1790 - even after the new constitution gave the National Government an independent power to levy taxes. The government's revenue expectations were in doubt given its inability to prevent smuggling and enforce tariff $(t)$ payments; in doubt given fluctuations in tariff revenues (the main source of tax revenue) due to ubiquitous fluctuations in foreign trade $\left(\mathbf{I}_{\mathrm{i}}\right)$ caused in part by uncertainty in trade treaty negotiations; and in doubt given questions about the government's ability to raise other taxes $\left(\mathbf{O}_{\mathrm{i}}\right)$ considering the public's willingness to engage in violent large-scale tax revolts, e.g. Shay's Rebellion 1786-1787, the Whiskey Rebellion 1794, and Fries' Rebellion $1798 .^{5}$

As such, the net asset position of the U.S. National Government may have been especially important in this period to establishing and then sustaining its creditworthiness. A positive net asset position would have been viewed as a potential safety valve to the pressure of increasing $k$ to balance unexpected budget shortfalls in a world where the government's reputation and yearly tax revenue capacity were still in doubt.

\section{Were Land Assets Viewed as Backing the National Government's Debt?}

The linkage of land to public finance was deeply rooted in the American experience. Colonial governments formed land banks where a subject's land served as collateral or security for loans of government paper money. A colony's paper bills of credit were understood as being backed by the mortgaged land assets of the colony 
(Kemmerer, 1939; Newell, 1998, pp. 215-229; Perkins, 1994, pp. 44-46; Ratchford, 1941, pp. 10-12, 18, 21-22). Similarly, states made use of land to back and pay off their Revolutionary War debts. And in the state cessions of lands to the National Government, some states retained "reserve" lands for paying soldiers and war debts, e.g. Virginia and Connecticut held on to sizable chunks of Ohio as their "western and military reserve" lands. Land being used to back public debt was not a strange concept—it was a first and obvious consideration of people in this era (Behrens, 1923, pp. 69-77; Donaldson, 1884, pp. 82-85; Gates, 1968, p. 62; Hibbard, 1939, pp. 10-14, 53; and Figure 1 below).

In the early Congressional debates over western lands ceded to the National Government, using said lands to back or pay off the national war debt was a prominent theme (Donaldson, 1884, pp. 60-81; Gates, 1968, p. 61). In 1779 congressmen from Delaware and Maryland asserted that the western territories were "gained from the King of Great Britain, or the native Indians, by the blood and treasure of all, and ought therefore to be a common estate, to be granted out on terms beneficial to the United States." (Donaldson, 1884, pp. 61-62) In 1780 congressmen from New York asserted that the, “... uncultivated territory within the limits or claims of certain States ought to be appropriated as a common fund for the expenses of the war..." (Donaldson, 1884, p. 63) Later in 1780 , Congress resolved that all lands so ceded by the states to the National Government "shall be disposed of for the common benefit of the United States..." (Donaldson, 1884, p. 64) The obvious common benefit was to service the National Debt. After 1780, Congress continually linked its land assets with the National Debt (Gates, 1968, pp. 61-62, 124; footnote 8 below). A Congressional Committee, reporting on September 5, 1782, favored "ceding of the western lands, to be sold to 'discharge the 
national debt." (Hibbard, 1939, p. 33) The Ordinance of 1784 pledged that the proceeds of the sale of public land now belonging or which may belong to the United States were to be used solely to pay off the National Debt until said debts were fully satisfied (Hibbard, 1939, pp. 4-5). A report to Congress in 1786 stated, "The whole product [from sales of western lands]...is appropriated for the payment of the principal and interest of the national debt, and no part thereof can be diverted to other purposes." (Syrett, 1962, v. 5, p. 63) ${ }^{6}$ Finally, the August 4, 1790 Funding Act (United States Congress, Register of Debates in Congress (House of Representatives), v. 2, p. 2311) stated,

That the proceeds of the sales which shall be made of lands in the western territory, now belonging, or that may hereafter belong, to the united states, shall be, and are hereby appropriated towards sinking or discharging the debts, for the payment whereof the United States now are, by virtue of this act may be, holden, and shall be applied solely to that use, until the said debts shall be fully satisfied.

Financiers, those involved in high finance as well as those involved in public

finance, also understood the importance of a pledge of security by the government to the backing of its debts and to the fostering of confidence in its debt position. For example, William Bingham, a director of the Bank of North America, in a letter to Alexander Hamilton, U.S. Treasury Secretary, on November 25, 1789 explained,

The Credit of the Funds [the National Debt] must essentially depend on the permanent Nature of the Security; \& if that is not to be relied on, they will fall in value, the disadvantage of which, Government will experience by the payment of an exorbitant Interest, whenever it is compelled to anticipate its revenues, by the Negotiation of domestic Loans. ... If we offer a less Substantial Security, we must Submit to a consequent Depreciation in the Value of our Funds.... A Government should therefore pledge every security it can offer, to engage the Confidence of the public Creditors, which, if once impaired, the pernicious Effects can be felt in all its future Dealings. (Syrett, 1962, v. 5, pp. 540-541)

Bingham's reference to "security" of a "permanent nature" would seem to mean government capital assets. And the only capital assets the government possessed at this 
time in any substantial quantities were its western lands. ${ }^{7}$

Along a similar vein, Hamilton in July of 1782 wrote, "The disposal of the unlocated lands will hereafter be a valuable source of revenue, and an immediate one of credit." (Syrett, 1961, v. 3, p. 105-italic added) In a letter to Nathaniel Chipman, July 22, 1788, dealing with how the National Debt might affect Vermont tax-wise if it joined the union, Hamilton said, "The public debt, as far as it can prudently be provided for, will be by the Western lands and the appropriation of some general fund." (Syrett, 1962, v. 5, p. 186) And in his January 1790 "Report on Public Credit" Hamilton said,

It is presumable, that no country will be able to borrow of foreigners upon better terms, than the United States, because none can, perhaps, afford so good security. Our situation exposes us less, than that of any other nation, to those casualties, which are the chief causes of expense; our incumbrances, in proportion to our real means, are less, though these cannot immediately be brought so readily into action, and our progress in resources from the early state of the country, and the immense tracts of unsettled territory, must necessarily exceed that of any other. The advantages of this situation have already engaged the attention of the European money-lenders... (Syrett, 1962, v. 6, p. 89)

Lastly, many schemes to swap land for debt in large amounts were planned in the years leading up to the 1790 Funding Act. Some failed to be executed and some were executed - though not all with success. For example, in 1787 the Ohio Company offered to purchase 1.5 million acres and the Scioto Company another 5 million acres of the public domain. In 1788 Judge John Cleves Symmes made a similar offer for 2 million acres between the Great and Little Miami Rivers (Donaldson, 1884, p. 17, Gates, 1968, pp. 70-71; Hibbard, 1938, pp. 44-55; Robbins, 1942, pp. 10-11).

The Founding Fathers were aware of these possibilities. Edward Carrington wrote to Thomas Jefferson on October 23, 1787, in reference to the schemes just mentioned, This mode of sale will relieve the U.S. of much expense, and the progress of the sales promise to be sufficiently rapid to give our people early relief from the 
pressure of the domestic debt. I am inclined to believe that some successful experiment might be made for the sale [of] a part of the territory in Europe, and have suggested a trial with a few Ranges of the surveyed Townships. (Boyd, 1955 , v. 12 , pp. 256-257)

And James Madison writing to Jefferson on October 24, 1787 reiterated the same information about potentially large land sales (Rutland, 1977, v. 10, p. 218).

William Findley, congressman from Pennsylvania, claimed that proposals for large sales of the public domain were still being made by 1790, but were being ignored by Hamilton. Findley said,

Flint and Parker had agreed to purchase three millions of acres. To the second session of the New Congress, Scriba made proposals for four or five millions. And Hannibal William Dobbyne proposed to take more than all the others, and to settle it with people from Ireland. These proposals were referred to the secretary of the treasury [Hamilton], while he was privately preparing the funding system: but he never reported on them....If the proposals of Messrs. Parker, Dobbyne, and others, which were offered before the funding system was originated, had been accepted, it is a moderate computation to suppose that fifteen millions of dollars would have been redeemed. (Taylor, 1950, p. 62)

He guessed that such schemes might reduce the debt to $\$ 6$ million.

Hamilton himself in his 1790 "Report on Public Credit" proposed one plan (perhaps disingenuously, see below) whereby a full third of the National Debt would be extinguished by swapping it for land- "The inducement to the measure [this particular plans] is, the payment of one third of the debt in land.” (Syrett, 1962, v. 6, pp. 91-92)

The point here is that contemporaries believed the National Government had pledged the public domain, and had the potential to sell large chunks of it if necessary, to cover and service the National Debt. ${ }^{8}$ But was there enough land to cover the National Debt or was the debt just too big?

\section{The National Debt, 1784-1802}

Several issues need to be addressed in the construction of a yearly time series for 
the U.S. National Debt during this period. First, even if the National Government's liabilities are confined just to its interest-bearing debt, yearly evidence on this exists only after 1790. From 1784 through 1790, these numbers must be estimated. Second, given that prices fluctuated greatly over this period (Bezanson, 1936, p.392; Cole, 1938, pp. 120-156; Grubb, 2003, pp. 1782-1783), inflation-adjusted debt exposure should be considered along side the nominal debt exposure. Third, in order to have a consistent time series for evaluation, some estimate of state debts pre-assumption (pre-1791) should be incorporated as the expected state debts to be assumed by the National Government. Fourth, the non-interest-bearing debt, the Continental Dollar, should be considered and incorporated in some way. The literature typically glosses over the non-interest-bearing debt - either not counting it at all or simply noting that it was worthless, defaulted on, or paid off at 100 to 1 without explaining the ramifications of this or why this debt could be treated differently than the interest-bearing debt. ${ }^{9}$

What is estimated here is the face value, and not the market value or the default value, of the National Debt. This is because the key question addressed is whether the National Government was financially solvent net asset-wise given the face value of its debt. In other words, could it honor the financial obligation clause in the new Constitution? Written in 1787, ratified by the states, and adopted by Congress by 1789 , this new U.S. Constitution said, "All Debts contracted and Engagements entered into before the Adoption of the Constitution, shall be as valid against the United States under this Constitution, as under the Confederation." (Article VI).

From 1781 through 1790 the National Government had been in default on both its interest-bearing and non-interest-bearing domestic debt (Taylor, 1950, p. 2). These debts 
traded in the marketplace at far below their face value and some citizens held them as speculative investments hoping for the day when better economic times and stronger political will would honor these debts at face value. The new Constitution, not only due to the above clause but due to the enhanced taxing power given the Federal Government, gave renewed hope that these debts would be un-defaulted and paid off at face value.

The winning arguments put forward by the "Federalist" for funding the interestbearing debt at face value in 1790 were both that the new U.S. Constitution obligated the Federal Government to honor its prior obligations as originally contracted, i.e. honor the face value, and that it was absolutely necessary for reestablishing the creditworthiness of the government. But these arguments would appear to hold equally well for paying off the Continental Dollar at face value. As in the colonial period, bills of credit such as Continental Dollars were non-interest-bearing contracts for payment which the issuing government had originally agreed to accept at face value for payment of the taxes it levied, effectively redeeming them at face value for public liabilities (taxes).

Printed on Continental Dollars were statements such as the following printed on the $\$ 80$ note: "The Bearer is entitled to receive EIGHTY Spanish milled DOLLARS, or an equal Sum in Gold or Silver according to a Resolution of Congress of the $14^{\text {th }}$ January, 1779" (Newman, 1997, pp. 59-68). The only difference in contractual obligation between Continental Dollars and other government debts was the non-payment of interest to holders of Continental Dollars. As such, the face value of the outstanding Continental Dollars, and not their market or default value, should be considered when assessing whether the National Government had the ability to un-default this debt circa 1790. This comparison may help explain the financial constraints that led Hamilton and Congress to 
reaffirm the government's default on the Continental Dollar while at the same time undefaulting its interest-bearing debt.

Table 1 presents yearly estimates of the face value of the National Government's liabilities from 1784 to 1802 , separately for the interest-bearing and non-interest-bearing debt in both nominal and real values, as well as incorporating the "expected" [in brackets] assumption of state war debts before 1791 and the actual assumption of state war debts after 1790.

[Place Table 1 Here]

\section{a. Estimating the Face Value of the Interest-Bearing Debt}

For the interest-bearing debt, the data for 1791-1802 are the official government statistics taken from the Historical Statistics (1975, part 2, p. 1104). For 1784-1790 these numbers are estimated as follows: $\$ 27$ million of principal at 6 percent annual interest is taken as the National Government's starting domestic debt in 1782 (Perkins, 1994, p. 213; Swanson, 1963, p. 48). No interest or principal was paid on this debt through 1790 so that \$27 million grew each year until reaching just over \$43 million in 1790 (Taylor, 1950, p. 2). This algorithm yields an estimate for the domestic portion of the National Debt in 1789 of $\$ 40,598,017$. This estimate closely matches the estimate of $\$ 40,414,086$ reported by Hamilton for 1789 (Taylor, 1950, p. 1; Syrett, 1962, v. 6, p. 86).

To this number each year is added $\$ 11,710,379$ of foreign debt owed by the National Government (Taylor, 1950, p. 1; Syrett, 1962, v. 6, pp. 85-86). Interest had been paid on this debt for the most part, but no principal (Perkins, 1994, p. 213). To this number each year is also added an estimate of $\$ 20,000,000$ of expected assumption of state debts [reported in brackets underneath each number] (Taylor, 1950, pp. 1, 4; 
Perkins, 1994, p. 215; Trotter, 1968, p. 372; United States Congress, Register of Debates in Congress (House of Representatives), v. 2, p. 1586 (April 21, 1790)). This estimation algorithm grafts onto and hits the starting value for the official statistics (the 1791 value) almost on the nose. ${ }^{10}$

\section{b. Face Value of the Continental Dollars Still Outstanding from 1784 to 1790}

The total amount of Continental Dollars emitted by the National Government, the total amount withdrawn, and the time series of the outstanding balances are not exactly known. A variety of estimates are offered in the literature. For example, in the modern published literature the total amount reported as emitted from 1775 (the first) through 1779 (the last) ranges from $\$ 204$ to $\$ 241.5$ million (e.g. see Calomiris, 1988, p. 58; Ferguson, 1961, p. 67; Michener, 1988, p. 690; Newman, 1997, pp. 58-69; Perkins, 1994, p. 103; Ratchford, 1941, p. 37; Swanson, 1963, p. 36). These estimates are in turn derived from estimates ranging from $\$ 191.5$ to $\$ 241.5$ million found in the older authoritative literature (e.g. see Bullock, 1895, p. 135; Elliot, 1843-44, p. 8; Harlow, 1929, pp. 50-51). The differences across these estimates are reconciled in Appendix Table A1. Some estimates suffer from errors of addition and some from errors of omission. But the major point of discrepancy comes from the amount of the $\$ 50$ million emission of January 14, 1779 that was exchanged for prior emissions (as instructed in the authorizing legislation) and how much leaked out as a net new emission. Lacking direct evidence, guesses in the literature vary widely, see Appendix Table A1.

The one hard data point for the total amount of Continental Dollars outstanding at a specific moment in time offered by Congress was on September 2, 1779 when it said there was $\$ 159,948,880$ outstanding on that date (Bullock, 1895, p. 136; Elliot, 1843-44, 
p. 8). The discrepancy between that number and the totals reported across the literature to that date were used to adjust the guesses across the literature about how much of the January 14, 1779 emission should be counted as new. When the addition and omission errors and the discrepancy just described are corrected across the literature, the result is a single consistent estimate of \$200,000,000 Continental Dollars emitted from 1775 through 1779 and still outstanding as of 1780, see Appendix Table A1. ${ }^{11}$ Taxes to pull these Continental Dollars out of circulation were not initiated in earnest until after 1780 (Ratchford, 1941, pp. 32-33, 37-38; and Appendix Table 2A).

With the requisition act of March 18, 1780, Congress defaulted on the Continental Dollar-no longer accepting it at face value but only at a rate of 40 Continental Dollars to 1 dollar in specie for payments of taxes and requisitions. While Continental Dollars traded at an even greater discount in the marketplace, the 40 to 1 rate remained that at which the National Government credited states for the payment of taxes to it from 1780 through 1789 (Boyd, 1953, v. 7, pp. 221-223; Bullock, 1895, pp. 136-138).

The amount of Continental Dollars (in face value) taxed out of circulation, remitted to the U.S. Treasury and burned between 1780 and 1790 under this policy is seldom discussed. Yet U.S. Treasury records report these amounts for 1780 through 1789 (Elliot, 1843-44, pp. 73-76). These numbers, slightly rearranged, are reproduced in Appendix Table A2. These sums, totaling \$119.5 million, are subtracted from the $\$ 200$ million of total emissions as of 1780 to get the time series reported in Table 1 of the face value of Continental Dollars still outstanding and unredeemed from 1784 through 1790.

Using this estimation algorithm leaves $\$ 80.5$ million Continental Dollars still outstanding and unredeemed in 1790 , which is close to Congress' guess of $\$ 78$ to $\$ 80$ 
million still unredeemed and unfunded in 1791 (Elliot, 1843-44, p. 12, item \#3), and close to Hamilton's implied estimate for 1789 (see footnote 10 above). Congress' guess of how many Continental Dollars were exchanged for bonds at the 100 to 1 default rate set after 1790 (by the 1790 Funding Act) was \$6 million (face value), leaving something around $\$ 72$ to $\$ 74$ million (face value) as a total loss, i.e. never funded or redeemed (Elliot, 1843-44, p. 12, item \#4). ${ }^{12}$

Apparently the requisition act of March 18, 1780 that set the default rate at 40 to 1 Continental Dollars to specie dollars in the payment of taxes led some citizens to hold on to Continental Dollars instead of using them to pay taxes, speculating that better days or a new political regime would un-default the Continental Dollar and redeem them at face value. For example, in 1784 one foreign observer noted in reference to the Continental Dollar, "At present there are many private Gentlemen holding large sums of Paper money, that is to be called in. But when this will happen, at what rate it will be redeemed, congress do not yet agree upon.” (Boyd, 1953, v. 7, p. 213) As such, even by 1790, 40 percent of the Continental Dollars were still outstanding (Bullock, 1895, p. 138). The same motive led people to purchase and hold the interest-bearing debt, even though no interest had been paid for a number of years and it traded at 20 cents on the dollar in the marketplace. They were speculating that better days or a new political regime would undefault the interest-bearing debt and redeem it at face value.

Under the Funding Act of August 4, 1790, Hamilton and Congress thrilled the speculators in the interest-bearing debt by making interest payments on this debt's face value to the current holders of the debt. They, however, disappointed the speculators in Continental Dollars by not only not un-defaulting the Continental Dollar but by 
increasing the default rate under which the National Government would accept Continental Dollars to 100 Continental Dollars for 1 dollar in interest-bearing bonds (Taylor, 1950, p. 62). Only $\$ 6$ million, of the $\$ 80$ million, Continental Dollars still outstanding in 1790 were so exchanged at that default rate between 1791 and $1797-$ when the exchange program was discontinued (Elliot, 1843-44, p. 12; Newman, 1997, p. 69). "The rest [\$74 million] seems to have remained in the hands of people who held it after the time fixed by the funding act, hoping that ultimately the notes would be redeemed in full.” (Bullock, 1895, p. 138) After 1797, however, they would be disappointed and nothing would be received —a total loss for those still holding these non-interest-bearing debt claims on the National Government.

\section{Deflation, Inflation, and the National Debt}

\section{a. Deflation and the Interest-Bearing Debt 1784-1790:}

Before 1790 and the Hamilton funding plan, the nominal interest-bearing debt grew mostly from non-payment of interest on the domestic portion of that debt. The real interest-bearing debt also grew due to deflation. From 1784 through 1789 the combined National and state interest-bearing debt grew by $\$ 10.3$ million in nominal value and $\$ 25.8$ million in real value. In other words, the growth in the real debt was due 40 percent to accumulating interest arrears and 60 percent to deflation. Thus, in the half decade leading into the formulation of Hamilton's funding plan in 1790, deflation may have been a bigger concern than interest arrears in assessing the National Government's ability to pay this interest-bearing debt. In real terms the interest-bearing debt peaked in 17891792 , just as the funding plan was being formulated and enacted.

Why did the Hamilton funding plan restructure the interest-bearing debt into 
callable perpetuities? Perhaps the rapid rise in the real value of the interest-bearing debt over the prior half-decade constrained Hamilton's choices. The smallest cash flow needed out of new taxes (the Hamiltonian tariff) to support the interest-bearing debt so it would trade at face value would result from turning this debt into perpetuities (Swanson, 1963, p. 50). ${ }^{13}$ The result of this expedient, however, was that it tied up the Federal budget with about 30 percent of annual revenues having to go to interest payments on the debt. At the end of the Adams administration the Federal Government was even led to borrow long-term to cover short-term liabilities - an unsustainable position (Taylor, 1950, p. 7). While the Federal Government met its interest payments throughout 1791-1802, whether it always could from current tax revenues was less than certain.

If this is the only explanation of the debt-funding method Hamilton favored, it does little to flatter him, for while it did fund the interest-bearing debt, it also tied up the Federal budget thus leaving the government in a precarious fiscal state over the next decade. It also makes his effort to dissuade Congress from swapping land for debt look fiscally irresponsible. Was there some other hidden, clever, or sinister reason afoot? b. Inflation and the Interest-Bearing Debt 1791-1802:

Between 1789-1791 and 1795-1802 prices rose about 50 percent. This was a permanent price rise - at least through 1818 (Bezanson, 1936, p. 392). Between 1792 and 1801, while the nominal value of the interest-bearing debt changed little, inflation reduced its real value by about 31 percent (see Table 1). Were the Federalist and Hamilton just lucky, or was there a causal link to Hamilton's funding plan? Did Hamilton intend to inflate his way out of a significant portion of the Federal debt? At least within Hamiltonian rhetoric it seems hard not to conclude that he may have so intended. 
Hamilton clearly understood the quantity theory of money, or at least a naïve

version of it. ${ }^{14}$ Money scarcity causes price deflation and when money is pumped into the economy, price inflation results. In his "Report on Public Credit" Hamilton wrote,

The value of cultivated lands, in most states, has fallen since the revolution from 25 to 50 per cent. ... This decrease, in the value of lands, ought, in a great measure, to be attributed to the scarcity of money. Consequently whatever produces an augmentation of the monied capital of the country, must have a proportional effect in raising that value. (Syrett, 1962, v. 6, p. 72) ${ }^{15}$

Later in 1790 he also wrote,

The stamping of paper [emission of paper money] is an operation so much easier than the laying of taxes, that a government, in the practice of paper emissions, would rarely fail in any such emergency to indulge itself too far... If it should not even be carried so far as to be rendered an absolute bubble, it would at least be likely to be extended to a degree, which would occasion an inflated and artificial state of things... (Syrett, 1963, v. 7, p. 322)

Hamilton also argued that the interest-bearing debt when funded by his plan

would turn this debt into paper money, meaning a circulating medium of exchange and not just bank vault assets. In the January 1790 "Report on Public Credit" Hamilton wrote,

[When]...the national debt is properly funded, and an object of established confidence, it answers most of the purposes of money. Transfers of stock or public debt are there equivalent to payments in specie; or in other words, stock, in the principal transactions of business, passes current as specie. ... [T] he public debt, by a provision for it on true principles, shall be rendered a substitute for money... (Syrett, 1962, v. 6, pp. 70-71)

The debt would become "asset" money, basically paper contract claims to a stream of Federal tariff revenues in the form of yearly interest payments in specie or banknotes. Thus, by Hamilton's own rhetoric, he was dumping about $\$ 52$ million of new cash into the domestic economy circa 1790-1792. ${ }^{16}$ This was a lot of money. The population of the U.S. in 1790 was about four million (Historical Statistics of the United States, 1975 , part 1, p. 8, Series A 6-8), which would imply about a \$13 per capita 
injection of money into the economy as a result of Hamilton's funding plan. By contrast, the total volume of money in the U.S. in 1790 (pre-Hamilton funding plan) was only about $\$ 3$ per capita (Hepburn, 1967, p. 87). Thus Hamilton's plan would lead to about a five fold increase in the domestic money supply.

However, being a near substitute to specie some of this money leaked out of the country - just as specie coins had from 1783 through 1789 due to the imbalance in foreign trade - via foreign purchases and ownership of the Federal debt (or effectual ownership of the stream of specie it commanded via debt-leverage over American importers of foreign goods). In addition, how much of the Federal debt actually served as investment assets and how much as circulating currency, i.e. what its velocity of circulation was, is unknown. And how much might have been absorbed through an increase in the monetization of transactions in the economy is also unknown (Grubb, 2005, p. 1343). Thus, the true monetary expansion would be less than five fold.

As such, the permanent price rise of around 50 percent that followed over the next few years, peaking in 1796, would seem to be an obvious and likely result of this Hamiltonian monetary injection—following Hamilton's own logic. ${ }^{17}$ And given Hamilton's statement (above) over proportionality of money increases to prices increases, Hamilton may have expected much more than a 50 percent price rise-something more in the range of a 400 percent price rise which would have reduced the real value of the Federal debt by a far greater amount between 1792 and 1801 than the 31 percent that was actually experienced — maybe more in the range of an 80 percent reduction.

This evidence and line of logical deduction turns the monetary rhetoric of the early Republic, as typically pontificated in the literature, on its head. Supposedly the 
Federalists argued that those who wanted states to issue paper money were simply debtors out to defraud their creditors by causing inflation so they could pay back their nominal debts in depreciated money-lowering the real value of their debts. The Federalist used this argument effectively to constitutionally take monetary powers away from state and national legislatures in 1787 (Grubb, 2003, 2006). Yet by Hamilton's own rhetorical logic, he had done just that, namely inflate his way out of debt. By Hamilton's own words and logic, he clearly advocated inflating the economy and so should not be viewed as a conservative on monetary issues but instead as an arch monetary activist and inflationist, or perhaps "re-inflationist," in his role as the Secretary of the Treasury. ${ }^{18}$

If this is the true explanation of the debt-funding method Hamilton favored, it does little to flatter him for it turns him into a premeditated inflationist— taking actions that by his own words and logic could have brought back hyper-inflation and wrecked the economy. Or was Hamilton's rhetoric here just that—rhetoric designed only to persuade those who desired more specie-linked money in the economy into supporting the debtfunding plan he favored? Was there some other clever and deeply hidden reason afoot?

\section{The National Government's Land Assets, 1784-1802}

Even if the primary asset of the National Government is taken to be the public domain, estimating the amount of acres the National Government possessed and their value year by year over this period is not straightforward. ${ }^{19}$ First, the cession of lands from the states to the National Government did not occur all at once, but at different times by different states from 1781 through 1802. In addition, some state land claims overlapped with other states, and some land had already been alienated before being ceded or was conditionally retained by the ceding state, see Figure 1 and the notes to 
Table 2. The evidence in the original sources is not organized as a net transfer of land year by year to the National Government. As such, the evidence has to be resorted and closely interpreted to estimate the net saleable land possessed by the National Government year by year over this period, see Table 2 .

[Place Figure 1 Here]

[Place Table 2 here]

By 1787, of the 222 million acres that would be ceded by the states to the National Government, roughly 75 percent had been so ceded. The remaining 25 percent would not be ceded until 1802 (by Georgia). The National Government also sold a small portion of the public domain between 1784 and 1802 . These transfers are identified by year of sale and subtracted from the total remaining available for sale. The public domain, net of sales, that was still in the possession of the National Government and potentially saleable was 106 million acres when the Treaty of Paris recognized U.S. sovereignty in 1784 . It grew to 164 million acres by 1787 , the year the Founding Fathers crafted a new U.S. Constitution. It more or less stayed at that level until 1802 when it grew to 220 million acres with the completion of the land cession by Georgia.

The difficult issue is how to assign a value to these land assets for the purpose of calculating a net asset position. Several approximations will be used. First, given that the true average price per acre of the public domain is unknown, the data in Tables 1 and 2 are used to back out what the average price would have to be for the National Government to be just solvent. This first approximation is reported in Table 3.

[Place Table 3 Here]

Looking just at the interest-bearing debt [including the assumption of state debts], 
if the average price per acre of the public domain was $\$ 0.50$, then between 1785 and 1802 the National Government was solvent in terms of having assets equal to or in excess of the value of its debt. By 1802 this price would only have to be $\$ 0.35$ per acre. As argued below, this price looks within the likely range of what the true average was.

By contrast, looking at the total interest-bearing plus non-interest-bearing debt [including the assumption of state debts], if the average price of the public domain was between $\$ 0.93$ and $\$ 1.02$ an acre, then between 1786 and 1790 the National Government would just be solvent. If the expected assumption of state debts are excluded then this number would be between $\$ 0.81$ and $\$ 0.89$. As argued below, both these sets of prices appear on the high side of the likely range of what the true average was.

Thus, as a first approximation, the National Government would appear to be solvent only if the non-interest-bearing debt—-the Continental Dollar —is eliminated, such as through Congress' 1790 reaffirmation of its absolute unwillingness to un-default it. The inclusion or exclusion of the expected assumption of state debts between 1784 and 1791 does not matter much. The National Government appears solvent in either case. The key to solvency was writing the non-interest-bearing debt off the ledger.

Table 4 refines this first approximation by using average prices per acre of the public domain that were actually mentioned and used at the time. This yields a "high to low" range for the value of the public domain. With the exception of the lowest price reported in Table 4-discussed below, the other prices are for actual sales of large tract of the public domain. Because land is extremely heterogeneous, only the sale of large tracts can give some reassurance that the average price observed is close to a true average price. Because these prices are reported for a specific year and given that prices fluctuate over 
this period, Table 4 inflation-adjusts them to get time series of average prices per acre. [Place Table 4 Here]

The lowest price series based on a large transfer, and what will be used hereafter as the "Best Guess Conservative Estimate," is for the Erie Triangle land transfer to Pennsylvania in 1792 [202,187 acres for $\$ 151,640$ or an average price of $\$ 0.75$ an acre] (Donaldson, 1884, pp. 17, 198). In the same inflation-adjusted range would be the average price of all public domain sold prior to $1800[1,281,860$ acres for $\$ 1,050,085$, i.e. $\$ 0.82$ an acre], and the proposed 1 million acre sale to Symmes in 1788 at $\$ 0.67$ an acre (Hibbard, 1939, pp. 51, 55, 100). By contrast, the highest overall inflation-adjusted price series comes from the cash sale of 72,974 acres for $\$ 117,108$ or $\$ 1.60$ an acre on average in 1787 at New York City (Donaldson, 1884, p. 17). While this was a cash sale, it also was small and selective, and so might represent only the sale of high valued acres.

The official minimum price set by Congress (which was not strictly adhered to) for purchasing the public domain, which had to be purchased in large tracts-i.e. a minimum purchase of a 640 acre lot, was $\$ 1.00 /$ acre in 1785 , raised to $\$ 2.00 /$ acre in 1796 , and then lowered to $\$ 1.25 /$ acre in 1820 (Robbins, 1942, pp. 15-16). If these prices are inflation adjusted from the year they were enacted back, they are all pretty much identical at $\$ 1.00$ /acre in 1785 dollars. ${ }^{20}$ On balance, the time series of real prices based on the nominal \$2.00/acre enacted in 1796 yields the highest price series among the official minimum prices enacted by Congress. An average price of $\$ 1.00$ /acre in 1785 or \$2.00/acre in 1796 (inflation-adjusted), therefore, would not necessarily be out-of-bounds for estimating the value of the public domain. However, the slowness of sales at these official prices suggests that these prices were on the high side of what was the true 
average price of the pubic domain. ${ }^{21}$ As such, the 1796 inflation-adjusted price of $\$ 2.00 /$ acre will be used as the upper range estimate of the value of the public domain.

Finally, for heuristic purposes a low estimate of $\$ 0.30$ an acre is also reported. This price does not come from an actual sale, but is the price that Hamilton proposed for extinguishing some of the principal of the National Debt by swapping it for western lands in his "Report on Vacant Lands" sent to Congress July 22, 1790 (Donaldson, 1884, pp. 198-199; Syrett, 1962, v. 6, p. 504). Hamilton also mentioned a price of $\$ 0.20$ an acre in his January 1790 "Report on Public Credit” (Syrett, 1962, v. 6, pp. 90-91). Hamilton combined two observations to deduce this land price. First, some of the public domain had been sold for $\$ 1.00$ an acre which could be paid for either in specie or in public debt at its face value. Second, the public debt, because it was in de facto default, had been trading for $\$ 0.20$ to $\$ 0.30$ per dollar of face value. Thus, Hamilton deduced that the price of an acre of land was not $\$ 1.00$ as announced but was really only $\$ 0.20$ to $\$ 0.30$.

Hamilton's deduction, however, is arbitrage inconsistent. Either anyone paying specie for land at the $\$ 1.00$ per acre price was a fool or anyone selling their public debt for $\$ 0.30$ per dollar of face value was a fool. Something is not right here, and Hamilton's price should be used with caution. Hamilton may have been intentionally undervaluing the price of land in his rhetoric to dissuade Congress from using land to retire debt and to persuade them to go with his plan to turn the debt into callable perpetuities. Alternatively, he may just have been honestly in error about land prices. Hamilton's rhetorical argumentation often has such a disingenuous tone that it hard to say. As such, it may be important to estimate the value of the National Government's land assets using Hamilton's land price in the off chance that he truly believed that that was the average 
price of an acre of the public domain.

Table 5 presents a range of estimates of the value of National Government's land assets from 1784 through 1802. Between 1784 and 1802, regardless of what price is used, the value of the public domain grew by 2.5 to 2.8 times. Using Hamilton's "low estimate" of $\$ 0.30$ an acre in 1790 , the value of the public domain was only $\$ 49$ million in 1790 when the National Debt funding plan was being put in place by Hamilton and Congress, rising to $\$ 90$ million by 1802 . Using the "Best Guess Conservative Estimate" of $\$ 0.75$ an acre in 1792 , the value of the public domain was $\$ 117$ million in 1790 , rising to $\$ 215$ million by 1802 . Using the other land price estimates makes these numbers much higher.

[Place Table 5 Here]

\section{The Net Asset Position of the National Government, 1784-1802}

Table 6 combines the information in Tables 1 and 5 to estimate the net asset position of the National Government from 1784 through 1802. It does so separately for just the interest-bearing portion of the National Debt as well as for the combined interestbearing and non-interest-bearing debt, including an estimate both with and without the expected assumption of state debts between 1784 and 1790 [in brackets for the former]. [Place Table 6 Here]

\section{a. Regarding the Interest-bearing Debt Only:}

At Hamilton's price of $\$ 0.30$ an acre at no time prior was the National Government solvent if it assumed state debts. Prior to the assumption of state debts (pre1791), the National Government, sans state debts, was marginally solvent from 1785 through 1787 and marginally insolvent from 1788 through 1790. Hamilton's insistence on the assumption of state debts in his 1790 funding plan, while arguably a politically 
savvy move, was financially reckless given his land price estimate—-pushing the National Government into a substantially insolvent position. Using Hamilton's land price would also indicate that the good credit rating the U.S. garnered in Europe by the 1790s was not due to its net asset position. So perhaps Hamilton's reckless plan was saved by a miracle.

However, Hamilton's land price, as argued above, seems excessively low by all the other evidence that exists. Hamilton may have been intentionally undervaluing the price of land in his rhetoric to dissuade some members of Congress from seriously considering swapping land for debt. Why this might have been a necessary, intentional, and clever strategy, and not just an honest mistake, will be addressed below.

If the "Best Guess Conservative Estimate" of $\$ 0.75$ an acre is used as the average price of the public domain, then the National Government was substantially solvent throughout the period vis-à-vis its interest-bearing debt even with the expected assumption of state debts. As such, the assumption of state debts was not a reckless financial act. And the good credit rating the U.S. garnered in Europe by the mid-1790s may have had as much to do with its positive net asset position as with Hamilton's funding plan. Under this interpretation Hamilton's debt-funding plan basically just solved the cash flow problem - raising annual tax revenues high enough to meet annual interest payments due on the face value of the debt-a miracle of sorts, but not incomprehensible. b. Regarding the Combined Interest-bearing and Non-interest-bearing Debt:

Between 1784 and 1791, adding the face value of the non-interest-bearing debt to that of the interest-bearing National and to-be-assumed state debts, the National Government was substantially insolvent when using the "Best Guess Conservative Estimate" of $\$ 0.75$ an acre for the price of the public domain. The average price of the 
public domain would have to be over $\$ 0.90$ an acre for it to be just solvent, an average land price which seems unlikely for this period. Even at the high estimate of $\$ 2.00$ an acre in 1796, the National Government was still insolvent in 1788 and 1789 if it assumed state debts. But the assumption of states debts was not the big issue. The government's net asset position was overwhelmed by the size of the non-interest-bearing debt.

In addition, given that tax revenues after 1790 were barely enough to pay the interest (and no principal) on the interest-bearing debt, converting the non-interestbearing debt into callable perpetuities paying 6 percent annually on its face value was outside the yearly revenue capabilities of the National Government. Doing so would have doubled the annual interest payment of the National Government, pushing interest payments on the National Debt from approximately 30 percent to something like 60 percent of annual revenue - which would have been an unsustainable position.

The outstanding non-interest-bearing debt (the Continental Dollar) was the "gorilla in the closet." By necessity the National Government had to default on it—which is what it did as part of the funding aspect of the financial revolution. In 1790, Hamilton advised reaffirming the old default rate of 40 to 1 set by Congress in 1781, but Congress opted for reaffirming the default at an even higher rate, namely at 100 to 1 (Ferguson, 1961, p. 296). Citizens holding Continental Dollars hoping that said dollars would be undefaulted and paid off at face value as Congress was about to do with the domestic interest-bearing debt were mightily disappointed (Taylor, 1950, p. 62).

Paying off the non-interest-bearing debt at 40 to 1 or at 100 to 1 probably didn't matter to the government's creditworthiness. It was a massive default in either case. And the 100-to-1-exchange was not for principal, but for interest-bearing bonds only, one 
third of which paid no interest until 1800. Thus turning in 100 Continental Dollars in 1791 did not yield $\$ 1$, but only $\$ 0.04$ at that year's end.

At 40 to 1 , the face value of the non-interest-bearing debt would be reduced to $\$ 2$ million and, at 100 to 1 to $\$ 0.81$ million. Even if all the outstanding Continental Dollars were turned in, the National Government would become substantial solvent with either default algorithm. The decision to reaffirm the default the Continental Dollar in 1790 was necessary to put the National Government back into a solvent position thereafter. But this required credibly distinguishing between its interest-bearing debt over which it was solvent and could fund interest payments in perpetuity out of tariff revenue, and its noninterest-bearing over which it was insolvent and had to default.

\section{Conclusions}

In 1790, the new Federal Government had to maintain the default on the Continental Dollar - the non-interest-bearing part of the National Debt it inherited from the Confederation period. But how could it do so without destroying its creditworthiness? The key was to legally and financially distinguish between the interest-bearing and the non-interest-bearing debt, and doing so determined the structure of the debt-funding part of the financial revolution.

At the Constitutional Convention in 1787 the Founding Fathers explicitly voted not to give the new Federal Government the power to emit additional non-interestbearing debt, i.e. bills of credit (Farrand, 1966, v. 2, pp. 308-310; Grubb 2006). Thus, the new Constitution distinguished between the Federal Government's interest-bearing debt — which it could continue to issue anew, and its non-interest-bearing debt—which it was no longer allowed to issue anew. But while this Constitutional distinction may have 
been a necessary condition, it was not a sufficient condition for preventing the default on the Continental Dollar from damaging the Federal Government's creditworthiness.

If the National Government paid any principal at face value, it could not credibly distinguish between its interest-bearing and its non-interest-bearing debt legally or in the marketplace. To default on the Continental Dollar without hurting its creditworthiness, it had to fund its debt in a way that paid no principal. The answer was to pay interest on the debt only. Since the Continental Dollar paid no interest, no funding provisions were required. This may explain why Hamilton devised a funding plan that turned the interestbearing debt into callable perpetuities, and why the Continental Dollar was redeemed for bonds and not for cash.

The National Government also had to curtail direct swaps of land for debt, because such swaps were payments of principal — at least until after the funding plan was established and after the default on the Continental Dollar had been successfully closed (at least until after 1797). As such, Hamilton's failure to report on proposed land-for-debt swaps in 1790 and his excessively low land price used in his reports to Congress in 1790 may have been intentional. He wanted to dissuade members of Congress from funding schemes that might involve swaps of land for debt which in turn would dissolve the distinction between the interest and the non-interest-bearing debt (Taylor, 1950, p. 62).

As such, the debt-funding aspect of the financial revolution is both less impressive and more complex than typically thought. In one sense, Hamilton's contribution to solving the National Government's financial situation was trivial-merely solving the immediate cash-flow revenue problem by meeting yearly interest payments on the debt via the Hamiltonian tariff. The long-run solvency problem was already solved 
by the spoils of war - the U.S. National Government's acquisition of land assets. But this debt-funding aspect of the financial revolution would have been all for naught if they could not find a way to permanently default on the Continental Dollar with impunity.

The genius of the U.S. financial revolution and its architects (Hamilton and the majority in Congress) was in recognizing that they had to legally and financially find a way to distinguish between the interest-bearing and the non-interest-bearing debt, and default on the latter without hurting the National Government's creditworthiness over the former. Their choices successfully put the gorilla in the closet, and the constraints of doing this explains the structure of the financial revolution enacted. The result was that the U.S. garnered an excellent credit rating in Europe soon after 1790 because it only had interest-bearing debt left. And its ability, in terms of actual tariff revenue and potential revenue from saleable land assets, to meet the interest payment on this debt and to eventually retire all this debt was well in excess of what was needed. It was substantially solvent net asset-wise post-1790. 


\section{References}

Adams, Randolph G., ed., Selected Political Essays of James Wilson. New York: Alfred A. Knolf, 1930.

Behrens, Kathryn L., "Paper Money in Maryland, 1727-1789," Johns Hopkins University Studies in Historical and Political Science, 41 (1923), pp. 9-98.

Bezanson, Anne, et al., Wholesale Prices in Philadelphia, 1784-1861. Philadelphia: University of Pennsylvania Press, 1936.

Bouton, Terry, "Tying Up the Revolution: Money, Power, and the Regulation in Pennsylvania, 1765-1800," Unpublished PhD Dissertation, Duke University, 1996.

Boyd, Julian P., The Papers of Thomas Jefferson. Princeton, NJ: Princeton University Press, Vols. 7-12, 1953-1955.

Bullock, Charles J., The Finances of the United States from 1775 to 1789, with Especial Reference to the Budget. Madison, WI: University of Wisconsin Press, 1895.

Calomiris, Charles W., "Institutional Failure, Monetary Scarcity, and the Depreciation of the Continental," Journal of Economic History, 48 (Mar. 1988), pp. 47-68.

Cole, Arthur Harrison, Wholesale Commodity Prices in the United States, 1700-1861. Cambridge, MA: Harvard University Press, 1938.

Donaldson, Thomas, The Public Domain. Washington, D.C.: Government Printing Office, 1884.

Elliot, Jonathan, "Funding System of the United States and Great Britain," House Document No. 15 (Vol. II. Executive Documents), $28^{\text {th }}$ Congress, $1^{\text {st }}$ Session, 1843-44.

Farrand, Max. ed., The Records of the Federal Convention of 1787. New Haven, CT: Yale University Press, Vols. 1-4, 1966.

Ferguson, E. James, The Power of the Purse. Chapel Hill, NC: University of North Carolina Press, 1961.

Gates, Paul Wallace, History of Public Land Law Development. Washington, D.C.: Zenger Publishing Company, 1968.

Gordon, John Steele, Hamilton's Blessing. New York: Penguin Books, 1998.

Grubb, Farley, "Growth of Literacy in Colonial America: Longitudinal Patterns, Economic Models, and the Direction of Future Research," Social Science History, 14 (Winter 1990), pp. 451-82. 
Grubb, Farley, "Creating the U.S. Dollar Currency Union, 1748-1811: A Quest for Monetary Stability or a Usurpation of State Sovereignty for Personal Gain?" American Economic Review, 93 (Dec. 2003), pp. 1778-1798.

Grubb, Farley, "State 'Currencies' and the Transition to the U.S. Dollar: ReplyIncluding a New View from Canada," American Economic Review, 95 (Sept. 2005), pp. 1341-1348.

Grubb, Farley, “The U.S. Constitution and Monetary Powers: An Analysis of the 1787 Constitutional Convention and How a Constitutional Transformation of the Nation's Monetary System Emerged," Financial History Review (forthcoming, 2006).

Harlow, Ralph Volney, “Aspects of Revolutionary Finance, 1775-1783,” American Historical Review, 35 (Oct. 1929), pp. 46-68.

Hepburn, A. Barton, A History of Currency in the United States. New York: Augustus M. Kelly, 1967 [original 1903].

Hibbard, Benjamin Horace, A History of the Public Land Policies. New York: Peter Smith, 1939.

Historical Statistics of the United States: Colonial Times to 1970. Washington, D.C.: U.S. Department of Commerce, 1975.

Jones, Alice Hanson, Wealth of a Nation to Be. New York: Columbia University Press, 1980.

Kemmerer, Donald L., “The Colonial Loan-Office System in New Jersey,” Journal of Political Economy, 47 (Dec. 1939), pp. 867-874.

Michener, Ron, "Backing Theories and the Currencies of Eighteenth-Century America: A Comment," Journal of Economic History, 48 (Sept. 1988), pp. 682-692.

Newell, Margaret Ellen, From Dependency to Independence: Economic Revolution in Colonial New England. Ithaca, NY: Cornell University Press, 1998.

Newman, Eric P., The Early Paper Money of America. Iola, WI: Krause Publications, $1997\left[4^{\text {th }}\right.$ edn. $]$.

Nettels, Curtis P., The Emergence of a National Economy, 1775-1815. New York: Harper \& Row, 1962.

North, Douglass C., The Economic Growth of the United States, 1790-1860. New York: W. W. Norton, 1966. 
Perkins, Edwin J., American Public Finance and Financial Services, 1700-1815.

Columbus, OH: Ohio State University Press, 1994.

Ratchford, B. U., American State Debts. Durham, NC: Duke University Press, 1941.

Richards, Leonard L., Shay's Rebellion: the American Revolution's Final Battle.

Philadelphia, PA: University of Pennsylvania Press, 2002.

Robbins, Roy M., Our Landed Heritage: The Public Domain, 1776-1936. Princeton, NJ:

Princeton University Press, 1942.

Rutland, Robert A., ed., Papers of James Madison. Charlottesville, VA: University Press of Virginia, Vols. 8-14, 1973-1983.

Stephenson, Nathaniel Wright, A History of the American People. New York: Charles Scribner's Sons, 1934.

Swanson, Donald F., The Origins of Hamilton's Fiscal Policy. Gainesville, FL:

University of Florida Press, 1963.

Swanson, Donald F., and Trout, Andrew P., "Alexander Hamilton, Conversion, and Debt Reduction,” Explorations in Economic History, 29 (Oct. 1992), pp. 417-429.

Syrett, Harold C., ed., Papers of Alexander Hamilton. New York: Columbia University Press, Vols. 2-17, 1961-1972.

Szatmary, David, Shay's Rebellion: the Making of an Agrarian Insurrection. Amherst, MA: University of Massachusetts Press, 1980.

Taylor, George Rogers, ed., Hamilton and the National Debt. Boston: D,C. Heath and Company, 1950.

Tindall, George Brown, America: a Narrative History. New York: W. W. Norton ( $2^{\text {nd }}$ edn.), 1988.

Trotter, Alexander, Observations on the Financial Position and Credit of Such of the States of the North American Union as Have Contracted Public Debts. New York: Augustus M. Kelly, 1968 [orig. 1839].

United States Congress, Register of Debates in Congress (House of Representatives), Vols. 1-5. (Washington, D.C.: Gales \& Seaton, 1825-1837. 
Figure 1. Land Ceded to the National Government by the 13 Original States

Source: Stephenson (1934, p. 248).

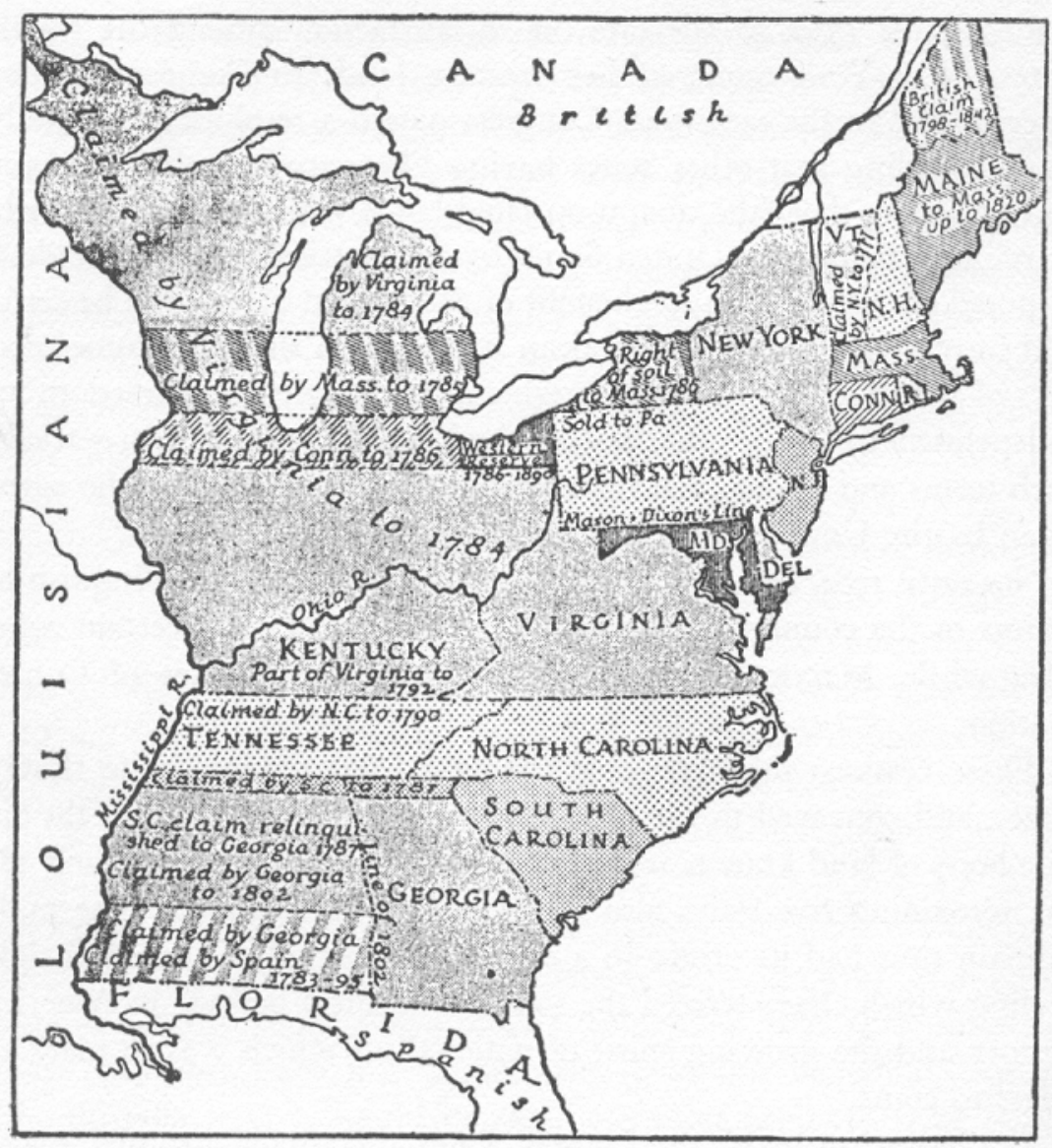

The Land Claims of the Thirteen States. 
Table 1. The Value of U.S. National Government Liabilities, 1784-1802

\begin{tabular}{|c|c|c|c|c|c|}
\hline Year & $\begin{array}{l}\text { Face Value of } \\
\text { National Interest- } \\
\text { Bearing Debt in } \\
\text { Nominal Dollars } \\
\text { Including [Expected] } \\
\text { And Actual Assumption } \\
\text { Of State Debts } \\
\text { (Interest and Principal) } \\
\quad \text { (1) }\end{array}$ & $\begin{array}{l}\text { Bezanson's } \\
\text { (1936, pp. } \\
\text { 392-393) } \\
\text { 140- } \\
\text { Commodity } \\
\text { Price Index } \\
\text { for } \\
\text { Philadelphia } \\
\quad \text { (2) }\end{array}$ & $\begin{array}{l}\text { Value of } \\
\text { National Interest- } \\
\text { Bearing Debt in } \\
\text { Deflated Real Dollars } \\
\text { Including [Expected] } \\
\text { and Actual Assumption } \\
\text { Of State Debts } \\
\text { (Interest and Principal) } \\
\quad \text { (3) }\end{array}$ & \multicolumn{2}{|c|}{$\begin{array}{l}\text { Paper Fiat Money Debt: } \\
\text { Face Value of National } \\
\text { Non-Interest-Bearing } \\
\text { Continental Dollar } \\
\text { Currency "Debt" Still } \\
\text { Outstanding (in Dollars) } \\
\text { Nominal Deflated Real } \\
\begin{array}{l}\text { (4) } \\
\text { (5) }\end{array}\end{array}$} \\
\hline 1784 & $\begin{array}{c}42,047,579 \\
{[62,047,579]}\end{array}$ & 100.1 & $\begin{array}{c}42,005,573 \\
{[61,985,593]}\end{array}$ & $119,728,392$ & $119,608,783$ \\
\hline 1785 & $\begin{array}{c}43,867,811 \\
{[63,867,811]}\end{array}$ & 94.1 & $\begin{array}{c}46,618,290 \\
{[67,883,219]}\end{array}$ & $119,728,392$ & $127,235,273$ \\
\hline 1786 & $\begin{array}{c}45,797,257 \\
{[65,797,257]}\end{array}$ & 91.0 & $\begin{array}{c}50,326,656 \\
{[72,304,678]}\end{array}$ & $99,295,015$ & $109,115,401$ \\
\hline 1787 & $\begin{array}{c}47,842,470 \\
{[67,842,470]}\end{array}$ & 88.4 & $\begin{array}{c}54,120,441 \\
{[76,744,875]}\end{array}$ & $93,606,254$ & $105,889,428$ \\
\hline 1788 & $\begin{array}{c}50,010,395 \\
{[70,010,395]}\end{array}$ & 83.3 & $\begin{array}{c}60,036,489 \\
{[84,046,092]}\end{array}$ & $85,604,491$ & $102,766,496$ \\
\hline 1789 & $\begin{array}{c}52,308,396 \\
{[72,308,396]}\end{array}$ & 82.4 & $\begin{array}{c}63,481,063 \\
{[87,046,907]}\end{array}$ & $80,537,630$ & $97,739,842$ \\
\hline 1790 & $\begin{array}{c}54,744,277 \\
{[74,744,277]}\end{array}$ & 86.5 & $\begin{array}{c}63,288,182 \\
{[86,409,568]}\end{array}$ & $80,537,630$ & $93,107,087$ \\
\hline 1791 & $77,228,000$ & 89.7 & $86,095,875$ & \multirow{12}{*}{\multicolumn{2}{|c|}{$\begin{array}{l}\text { [Hereafter subsumed into } \\
\text { the interest-bearing } \\
\text { National Debt in the } \\
\text { infamous } 100 \text { to } 1 \text { forced } \\
\text { swap for bonds. Only } \\
\text { about } \$ 6 \text { million were so } \\
\text { swapped leaving about } \\
\$ 74.5 \text { million out and not } \\
\text { redeemed or funded.] }\end{array}$}} \\
\hline 1792 & $80,359,000$ & 91.5 & $87,824,043$ & & \\
\hline 1793 & $78,427,000$ & 96.3 & $81,440,290$ & & \\
\hline 1794 & $80,748,000$ & 109.6 & $73,675,182$ & & \\
\hline 1795 & $83,762,000$ & 130.7 & $64,087,222$ & & \\
\hline 1796 & $82,064,000$ & 139.1 & $58,996,405$ & & \\
\hline 1797 & $79,229,000$ & 133.5 & $59,347,565$ & & \\
\hline 1798 & $78,409,000$ & 127.1 & $61,690,794$ & & \\
\hline 1799 & $82,976,000$ & 127.3 & $65,181,461$ & & \\
\hline 1800 & $83,038,000$ & 128.3 & $64,721,745$ & & \\
\hline 1801 & $80,713,000$ & 131.9 & $61,192,570$ & & \\
\hline 1802 & $77,055,000$ & 122.5 & $62,902,040$ & & \\
\hline
\end{tabular}


Notes and Sources: Column (1): Data for 1791-1802 are the official government statistics taken from the Historical Statistics (1975, part 2, p. 1104). For 1784-1790 this number is estimated as follows that described in the text. Column (2) is taken from Bezanson (1936, p. 392). Column (3) equals Column (1) / [Column (2)* 0.01]. Column (4) starts with the total of $\$ 200,000,000$ Continental Dollars emitted through 1779. See Appendix Table A1. From this total is subtracted the amount of Continental Dollars paid into the U.S. Treasury and burnt between 1780 and 1790 (Elliot, 1843-44, pp. 73-76). See Appendix Table A2. This leaves roughly $\$ 80.5$ million outstanding in 1790 , which is close to the U.S. Treasury's guess of $\$ 78$ to $\$ 80$ million still unredeemed and unfunded in 1791 (Elliot, 1843-44, p. 12, item \#3). The Treasury's guess of how many were exchange for bonds at 100 to 1 after 1790 was $\$ 6$ million, leaving something around $\$ 72$ to $\$ 74$ million as a total loss-never funded or redeemed (Elliot, 1843-44, p. 12, item \#4). Column (5) equals Column (4) / [Column (2)*0.01]. 
Table 2. U.S. National Government Land Assets: The Net Saleable Public Domain, 1784-1802

\begin{tabular}{|c|c|c|c|}
\hline Year & $\begin{array}{l}\text { Accumulated Total } \\
\text { National Public } \\
\text { Domain (Cession } \\
\text { Of Western Lands } \\
\text { Claimed by the } \\
\text { Original } 13 \text { States) } \\
\quad \text { In Acres } \\
\quad(1)\end{array}$ & $\begin{array}{l}\text { Public Domain } \\
\text { Sold by the } \\
\text { U.S. National } \\
\text { Government } \\
\text { In Acres } \\
\quad(2)\end{array}$ & $\begin{array}{l}\text { Total Net } \\
\text { Saleable Public } \\
\text { Domain in the } \\
\text { Possession of } \\
\text { the U.S. National } \\
\text { Government } \\
\quad \text { In Acres } \\
\quad \text { (3) }\end{array}$ \\
\hline$\overline{1784}$ & $105,801,867$ & & $105,801,867$ \\
\hline 1785 & $140,361,867$ & & $140,361,867$ \\
\hline 1786 & $162,161,867$ & & $162,161,867$ \\
\hline 1787 & $165,297,867$ & 895,874 & $164,401,993$ \\
\hline 1788 & $165,297,867$ & 248,540 & $164,153,453$ \\
\hline 1789 & $165,297,867$ & & $164,153,453$ \\
\hline 1790 & $165,297,867$ & & $164,153,453$ \\
\hline 1791 & $165,297,867$ & & $164,153,453$ \\
\hline 1792 & $165,297,867$ & 202,187 & $163,951,266$ \\
\hline 1793 & $165,297,867$ & & $163,951,266$ \\
\hline 1794 & $165,297,867$ & & $163,951,266$ \\
\hline 1795 & $165,297,867$ & & $163,951,266$ \\
\hline 1796 & $165,297,867$ & 43,446 & $163,907,820$ \\
\hline 1797 & $165,297,867$ & & $163,907,820$ \\
\hline 1798 & $165,297,867$ & & $163,907,820$ \\
\hline 1799 & $165,297,867$ & & $163,907,820$ \\
\hline 1800 & $165,297,867$ & 67,751 & $163,840,069$ \\
\hline 1801 & $165,297,867$ & 497,939 & $163,342,130$ \\
\hline 1802 & $221,987,787$ & 271,081 & $219,760,969$ \\
\hline
\end{tabular}

Notes and Sources: Column (1) is derived from Donaldson (1884, p. 11); Gates (1968, p. 57); Hibbard (1939, p. 13). Hibbard's low number for Virginia is used as it appears to accounts for some additional restrictions on land transfers that Donaldson and Gates seem to miss. North Carolina's cession of 
29,184,000 acres in 1790 was not counted as most of this land, being in Tennessee, had already been alienated. The time path of accumulation of acres was organized by using the year of each state's cession for the portion of land that was undisputed by other states, and for disputed lands among several states by using the latest year of cession among the states claiming that land. Virginia's military tract and the Western Reserve were excluded. Figuring out both the total and the time path of land acquisition from these sources is not an obvious exercise. The data must be resorted and so these figures must be regarded as estimates. For example, between 1781 and 1802 total National land acquisition in acres is given as 267,730,560 by Hibbard (1939, p. 31); 259,171,787 by Donaldson (1884, p. 11); 233,416,000 by the Historical Statistics (1975, part 1, p. 428); 233,415,680 by Gates (1968, p. 86); 224,975,200 by Gates (1968, p. 57). Thus, the numbers given here could be considered a conservatively low estimate.

Column (2) is derived from Donaldson (1884, p. 17) and Hibbard (1939, pp. 55, 100). Hibbard's adjustment to Donaldson's numbers regarding the size and dating of some sales is used.

Column (3) is Column (1) after netting out the lands sold in Column (2). 
Table 3. Average Land Price per Acre That Would Yield a Zero Net Asset Position Each Year for The U.S. National Government, 1784-1802 (Nominal Dollars)

\begin{tabular}{|c|c|c|}
\hline Year & $\begin{array}{l}\text { Interest-Bearing Debt Only } \\
\text { [Plus Expected Assumption of State Debts] }\end{array}$ & $\begin{array}{l}\text { Interest and Non-Interest-Bearing Debt } \\
\text { [Plus Expected Assumption of State Debts] }\end{array}$ \\
\hline 1784 & $\begin{array}{l}\$ 0.40 \\
{[0.59]}\end{array}$ & $\begin{array}{l}\$ 1.53 \\
{[1.72]}\end{array}$ \\
\hline 1785 & $\begin{array}{c}0.31 \\
{[0.46]}\end{array}$ & $\begin{array}{c}1.17 \\
{[1.31]}\end{array}$ \\
\hline 1786 & $\begin{array}{c}0.28 \\
{[0.41]}\end{array}$ & $\begin{array}{c}0.89 \\
{[1.02]}\end{array}$ \\
\hline 1787 & $\begin{array}{c}0.29 \\
{[0.41]}\end{array}$ & $\begin{array}{r}0.86 \\
{[0.98]}\end{array}$ \\
\hline 1788 & $\begin{array}{c}0.30 \\
{[0.43]}\end{array}$ & $\begin{array}{c}0.83 \\
{[0.95]}\end{array}$ \\
\hline 1789 & $\begin{array}{c}0.32 \\
{[0.44]}\end{array}$ & $\begin{array}{c}0.81 \\
{[0.93]}\end{array}$ \\
\hline 1790 & $\begin{array}{c}0.33 \\
{[0.46]}\end{array}$ & $\begin{array}{c}0.82 \\
{[0.95]}\end{array}$ \\
\hline 1791 & 0.47 & \\
\hline 1792 & 0.49 & \\
\hline 1793 & 0.48 & \\
\hline 1794 & 0.49 & \\
\hline 1795 & 0.51 & \\
\hline 1796 & 0.50 & \\
\hline 1797 & 0.48 & \\
\hline 1798 & 0.48 & \\
\hline 1799 & 0.51 & \\
\hline 1800 & 0.51 & \\
\hline 1801 & 0.49 & \\
\hline 1802 & 0.35 & \\
\hline
\end{tabular}

Notes and Sources: Table 1 column (1) divided by Table 2 column (3) and Table 1 columns [(1) + (4)] divided by Table 2 column (3), respectively. 
Table 4. Inflation-Adjusted Nominal Price Per Acre of U.S. National Government Land, 1784-1802

\begin{tabular}{|c|c|c|c|c|c|c|}
\hline & $\begin{array}{l}\$ 0.30 \\
\text { An Acre } \\
\text { In } 1790\end{array}$ & $\begin{array}{l}\$ 0.75 \\
\text { An Acre } \\
\text { In } 1792\end{array}$ & $\begin{array}{l}\$ 1.00 \\
\text { An Acre } \\
\text { In } 1785\end{array}$ & $\begin{array}{l}\$ 1.25 \\
\text { An Acre } \\
\text { In } 1820\end{array}$ & $\begin{array}{l}\$ 1.60 \\
\text { An Acre } \\
\text { In } 1787\end{array}$ & $\begin{array}{l}\$ 2.00 \\
\text { An Acre } \\
\text { In } 1796\end{array}$ \\
\hline 1784 & 0.34 & 0.81 & 1.06 & 1.17 & 1.79 & 1.22 \\
\hline 1785 & 0.32 & 0.77 & $1.00 *$ & 1.09 & 1.69 & 1.10 \\
\hline 1786 & 0.31 & 0.75 & 0.97 & 1.06 & 1.64 & 1.04 \\
\hline 1787 & 0.31 & 0.73 & 0.94 & 1.02 & $1.60 *$ & 0.99 \\
\hline 1788 & 0.29 & 0.69 & 0.89 & 0.96 & 1.52 & 0.88 \\
\hline 1789 & 0.29 & 0.68 & 0.88 & 0.95 & 1.50 & 0.87 \\
\hline 1790 & $0.30^{*}$ & 0.71 & 0.92 & 1.00 & 1.57 & 0.95 \\
\hline 1791 & 0.31 & 0.74 & 0.96 & 1.04 & 1.62 & 1.01 \\
\hline 1792 & 0.32 & $0.75^{*}$ & 0.97 & 1.06 & 1.65 & 1.05 \\
\hline 1793 & 0.33 & 0.79 & 1.02 & 1.12 & 1.73 & 1.14 \\
\hline 1794 & 0.37 & 0.89 & 1.16 & 1.29 & 1.94 & 1.41 \\
\hline 1795 & 0.43 & 1.04 & 1.37 & 1.55 & 2.28 & 1.83 \\
\hline 1796 & 0.46 & 1.11 & 1.45 & 1.66 & 2.41 & $2.00 *$ \\
\hline 1797 & 0.44 & 1.07 & 1.39 & 1.59 & 2.32 & 1.89 \\
\hline 1798 & 0.42 & 1.02 & 1.33 & 1.51 & 2.22 & 1.76 \\
\hline 1799 & 0.42 & 1.02 & 1.33 & 1.51 & 2.22 & 1.76 \\
\hline 1800 & 0.43 & 1.03 & 1.34 & 1.52 & 2.24 & 1.78 \\
\hline 1801 & 0.44 & 1.05 & 1.38 & 1.57 & 2.30 & 1.86 \\
\hline 1802 & 0.41 & 0.98 & 1.28 & 1.45 & 2.15 & 1.67 \\
\hline
\end{tabular}

Notes and Sources: The nominal prices listed are inflated/deflated over time using the Bezanson (1936, pp. 392-393) 140-Commodity Price Index by taking the nominal price as reported for its given year as the true value for that year of an average acre of public land. This price is then taken as equal to 100 for the price index and the Bezanson price index is renormalized to that year. By multiplying that price by its particular renormalized price index (times 0.01 ) this nominal price is inflation/deflation-adjusted to other years.

* indicates the year the nominal price was observed. 
The $\$ 0.30$ price is from Hamilton's July 20, 1790 "Plan for the Disposition of the Public Lands" or "Report on Vacant Lands" sent to Congress July 22, 1790 (Donaldson, 1884, pp. 198-199; Syrett, 1962, v. 6, pp. 502-506).

The $\$ 0.75$ price is from the actual sale of a large seemingly representative block of land in 1792 the average price for the Erie Triangle land transfer to Pennsylvania (202,187 acres for \$151,640, see Donaldson (1884, pp. 17, 198)).

The $\$ 1.00$ price is Congress' minimum price per acre set in the land ordinance of 1785 which held until it was changed to $\$ 2.00$ an acre in 1796 (Donaldson, 1884, p. 197; Hibbard, 1939, pp. 37-41).

The $\$ 1.25$ price is the official minimum land sale price set by Congress in 1820 (Donaldson, 1884, p. 205; Gates, 1968, pp. 127, 140-142; Hibbard, 1939, pp. 63-64).

The $\$ 1.60$ price comes from the average price realized on the cash sale of 72,974 acres for $\$ 117,108$ in 1787 at New York City (see Donaldson, 1884, p. 17).

Lastly, the $\$ 2.00$ price is the official minimum land sale price set by Congress in 1796 through 1820 (see Donaldson, 1884, pp. 200-201; Gates, 1968, pp. 125-133). 
Table 5. Current Dollar Value of U.S. National Government Land Assets, 1784-1802

\begin{tabular}{|c|c|c|c|c|c|c|}
\hline \multirow[b]{2}{*}{ Year } & \multicolumn{6}{|c|}{$\begin{array}{l}\text { Dollar Value of the National Government Land Assets (Net Saleable Public Domain) Evaluated } \\
\text { At Different Estimated Nominal Average Prices per Acre as Inflation Adjusted in Table } 4\end{array}$} \\
\hline & $\begin{array}{l}\text { At } \\
\$ 0.30 \\
\text { In } 1790\end{array}$ & $\begin{array}{l}\text { At } \\
\$ 0.75 \\
\text { In } 1792\end{array}$ & $\begin{array}{l}\text { At } \\
\$ 1.00 \\
\text { In } 1785\end{array}$ & $\begin{array}{l}\text { At } \\
\$ 1.25 \\
\text { In } 1820\end{array}$ & $\begin{array}{l}\text { At } \\
\$ 1.60 \\
\text { In } 1787\end{array}$ & $\begin{array}{l}\text { At } \\
\$ 2.00 \\
\text { In } 1796\end{array}$ \\
\hline 1784 & $35,972,635$ & $85,699,512$ & $112,149,979$ & $123,788,184$ & $189,385,342$ & $129,078,278$ \\
\hline 1785 & $44,915,797$ & $108,078,638$ & $140,361,867$ & $152,994,435$ & $237,211,555$ & $154,398,054$ \\
\hline 1786 & $50,270,179$ & $121,621,400$ & $157,297,011$ & $171,891,579$ & $265,945,462$ & $168,648,342$ \\
\hline 1787 & $50,964,618$ & $120,013,455$ & $154,537,873$ & $167,690,033$ & $263,043,188$ & $162,757,973$ \\
\hline 1788 & $47,604,501$ & $113,265,883$ & $146,096,573$ & $157,587,315$ & $249,513,249$ & $144,455,039$ \\
\hline 1789 & $47,604,501$ & $111,624,348$ & $144,455,039$ & $155,945,780$ & $246,230,180$ & $142,813,504$ \\
\hline 1790 & $49,246,036$ & $116,548,952$ & $151,021,177$ & $164,153,453$ & $257,720.921$ & $155,945,780$ \\
\hline 1791 & $50,887,570$ & $121,473,555$ & $157,587,315$ & $170,719,591$ & $265,928,594$ & $165,794,988$ \\
\hline 1792 & $52,464,405$ & $122,963,450$ & $159,032,728$ & $173,788,342$ & $270,519,589$ & $172,148,829$ \\
\hline 1793 & $54,103,918$ & $129,521,500$ & $167,230,291$ & $183,625,418$ & $283,635,690$ & $186,904,443$ \\
\hline 1794 & $60,661,968$ & $131,161,013$ & $190,183,469$ & $211,497,133$ & $318,065,456$ & $231,171,285$ \\
\hline 1795 & $70,499,044$ & $170,509,317$ & $224,613,234$ & $254,124,462$ & $373,808,887$ & $300,030,817$ \\
\hline 1796 & $75,397,597$ & $181,937,680$ & $237,666,339$ & $272,086,981$ & $395,017,846$ & $327,815,640$ \\
\hline 1797 & $72,119,441$ & $175,381,367$ & $227,831,870$ & $260,613,434$ & $380,266,142$ & $309,785,780$ \\
\hline 1798 & $68,841,284$ & $167,185,976$ & $217,997,401$ & $247,500,808$ & $363,875,360$ & $288,477,763$ \\
\hline 1799 & $68,841,284$ & $167,185,976$ & $217,997,401$ & $247,500,808$ & $363,875,360$ & $288,477,763$ \\
\hline 1800 & $70,451,230$ & $168,755,271$ & $219,545,693$ & $249,036,905$ & $367,001,755$ & $291,635,323$ \\
\hline 1801 & $71,870,537$ & $171,509,237$ & $225,412,139$ & $256,447,144$ & $375,686,899$ & $303,816,362$ \\
\hline 1802 & $90,101,997$ & $215,365,750$ & $281,294,040$ & $318,653,405$ & $472,486,083$ & $367,000,818$ \\
\hline
\end{tabular}

Notes and Sources: Price per Acre indicated in each Column comes from the inflation/deflation adjustments to this price in Table 4. The acres of public domain come from Table 2, Column 3. 
Table 6. The Net Asset Position of the U.S. National Government, 1784-1802 (Nominal Dollars)

\begin{tabular}{|c|c|c|c|c|c|c|}
\hline & $\begin{array}{r}\text { Inter } \\
\text { [Plus Expectec }\end{array}$ & $\begin{array}{l}\text { est-Bearing Debt } \\
\text { Assumption of }\end{array}$ & $\begin{array}{l}\text { tonly } \\
\text { State Debts] }\end{array}$ & $\begin{array}{l}\text { Interest and } \\
\text { [Plus Expect }\end{array}$ & $\begin{array}{l}\text { Von-Interest-Bear } \\
\text { d Assumption of }\end{array}$ & $\begin{array}{l}\text { ing Debt } \\
\text { State Debts] }\end{array}$ \\
\hline & Hamilton's & Best Guess & $\$ 2 /$ Acre & Hamilton's & Best Guess & $\$ 2 /$ Acre \\
\hline & Low & Conservative & High & Low & Conservative & High \\
\hline Year & Estimate & Estimate & Estimate & Estimate & Estimate & Estimate \\
\hline 1784 & $-6,074,944$ & $+43,651,933$ & $+87,030,699$ & $-125,803,336$ & $-76,076,459$ & $-32,697,693$ \\
\hline & {$[-26,074,944]$} & {$[+23,651,933]$} & {$[+67,030,699]$} & {$[-145,803,336]$} & {$[-96,076,459]$} & {$[-52,697,693]$} \\
\hline 1785 & $+1,047,986$ & $+64,210,827$ & $+110,530,243$ & $-118,680,406$ & $-55,517,565$ & $-9,198,149$ \\
\hline & {$[-18,952,014]$} & {$[+44,210,827]$} & {$[+90,530,243]$} & {$[-138,680,406]$} & {$[-75,517,565]$} & {$[-29,198,149]$} \\
\hline 1786 & $+4,472,922$ & $+75,824,143$ & $+122,851,085$ & $-94,822,093$ & $-23,470,872$ & $+23,556,070$ \\
\hline & {$[-15,527,078]$} & {$[+55,824,143]$} & {$[+102,851,085]$} & {$[-114,822,093]$} & {$[-43,470,872]$} & {$[+3,556,070]$} \\
\hline 1787 & $+3,122,148$ & $+72,170,985$ & $+114,915,503$ & $-90,484,106$ & $-21,435,269$ & $+21,309,249$ \\
\hline & {$[-16,877,852]$} & {$[+52,170,985]$} & {$[+94,915,503]$} & {$[-110,484,106]$} & {$[-41,435,269]$} & {$[+1,309,249]$} \\
\hline 1788 & $-2,405,894$ & $+63,255,488$ & $+94,444,644$ & $-88,010,385$ & $-22,349,003$ & $+8,840,153$ \\
\hline & {$[-22,405,894]$} & {$[+43,255,488]$} & {$[+74,444,644]$} & {$[-108,010,385]$} & {$[-42,349,003]$} & {$[-11,159,847]$} \\
\hline 1789 & $-4,703,895$ & $+59,315,952$ & $+90,505,108$ & $-85,241,525$ & $-21,221,678$ & $+9,967,478$ \\
\hline & {$[-24,703,895]$} & {$[+39,315,952]$} & {$[+70,505,108]$} & {$[-105,241,525]$} & {$[-41,221,678]$} & {$[-10,032,522]$} \\
\hline 1790 & $-5,498,241$ & $+61,804,675$ & $+101,201,503$ & $-86,035,871$ & $-18,732,955$ & $+20,663,873$ \\
\hline & {$[-25,498,241]$} & {$[+41,804,675]$} & {$[+81,201,503]$} & {$[-106,035,871]$} & {$[-38,732,955]$} & {$[+663,873]$} \\
\hline 1791 & $-26,340,430$ & $+44,245,555$ & $+88,566,988$ & [Hereafter, th & e non-interest-bea & aring debt is \\
\hline 1792 & $-27,894,595$ & $+42,604,450$ & $+91,789,829$ & interest-beari & a debt.] & \\
\hline 1793 & $-24,323,082$ & $+51,094,500$ & $+108,477,443$ & & & \\
\hline 1794 & $-20,086,032$ & $+50,413,013$ & $+150,423,285$ & & & \\
\hline 1795 & $-13,262,956$ & $+86,747,317$ & $+216,268,817$ & & & \\
\hline 1796 & $-6,666,403$ & $+99,873,680$ & $+245,751,640$ & & & \\
\hline 1797 & $-7,109,559$ & $+96,152,367$ & $+230,556,780$ & & & \\
\hline 1798 & $-9,567,716$ & $+88,956,976$ & $+210,068,763$ & & & \\
\hline 1799 & $-14,134,716$ & $+84,209,976$ & $+205,501,763$ & & & \\
\hline 1800 & $-12,586,770$ & $+85,717,271$ & $+208,597,323$ & & & \\
\hline 1801 & $-8,842,463$ & $+90,796,237$ & $+223,103,362$ & & & \\
\hline 1802 & $+13,046,997$ & $+138,310,750$ & $+289,945,818$ & & & \\
\hline
\end{tabular}


Notes and Sources: The net asset position equals the nominal values in Table 5 minus the nominal values in Table 1 Columns 1 and 4 each year. The Low Estimate uses Hamilton’s $\$ 0.30$ price per acre. The Best Guess Conservative Estimate uses the $\$ 0.75$ price per acre. The High Estimate uses the $\$ 2.00$ price per acre. See the notes to Table 4 and the text for discussion. The Interest and Non-Interest-Bearing Debt includes the nominal face value of the Continental Dollar Fiat Currency added to the interest-bearing debt. 


\section{APPENDIX}

Table A1. Continental Dollars Emitted by Congress, 1775-1780: Reconciliation of Estimates

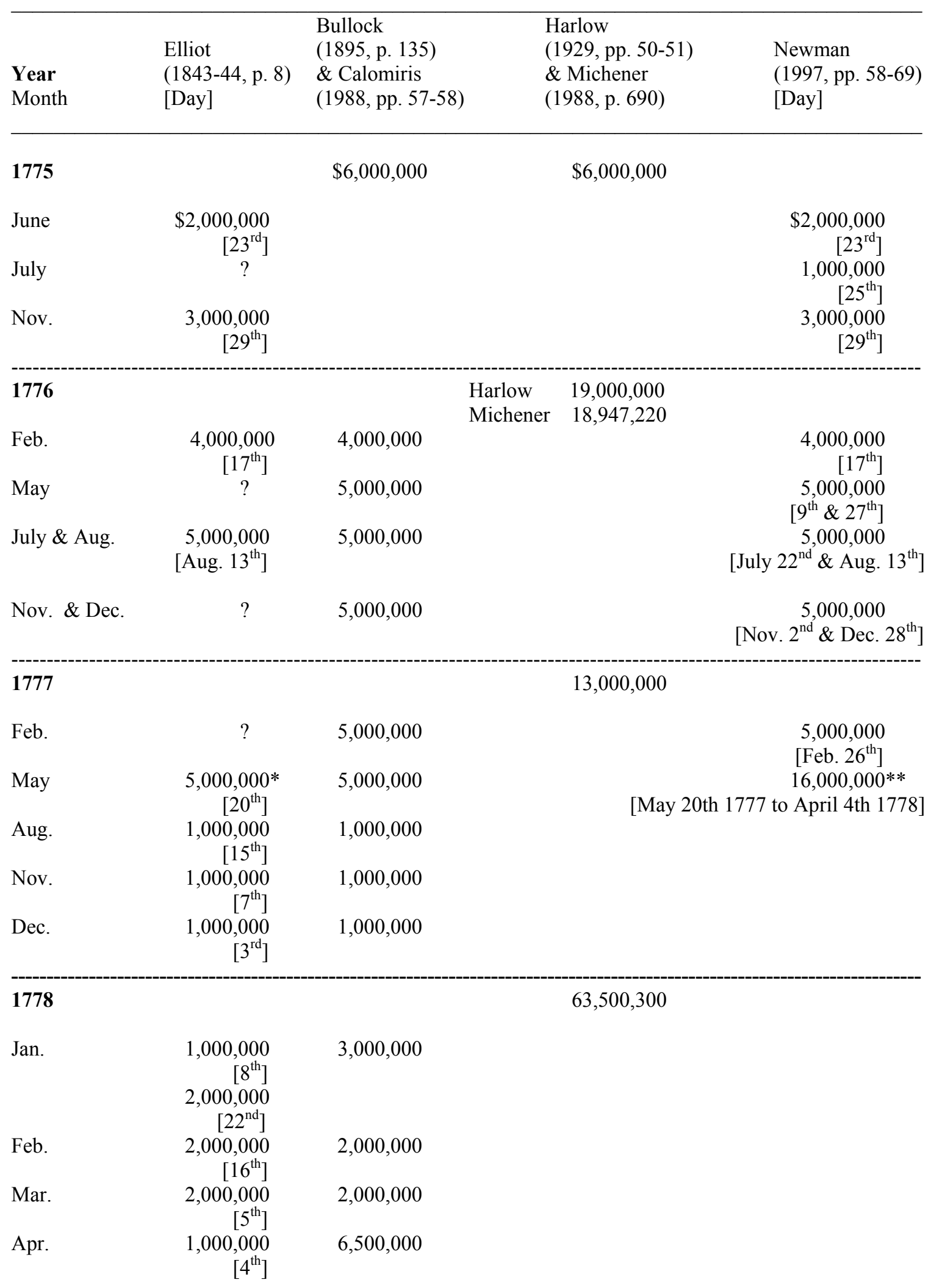




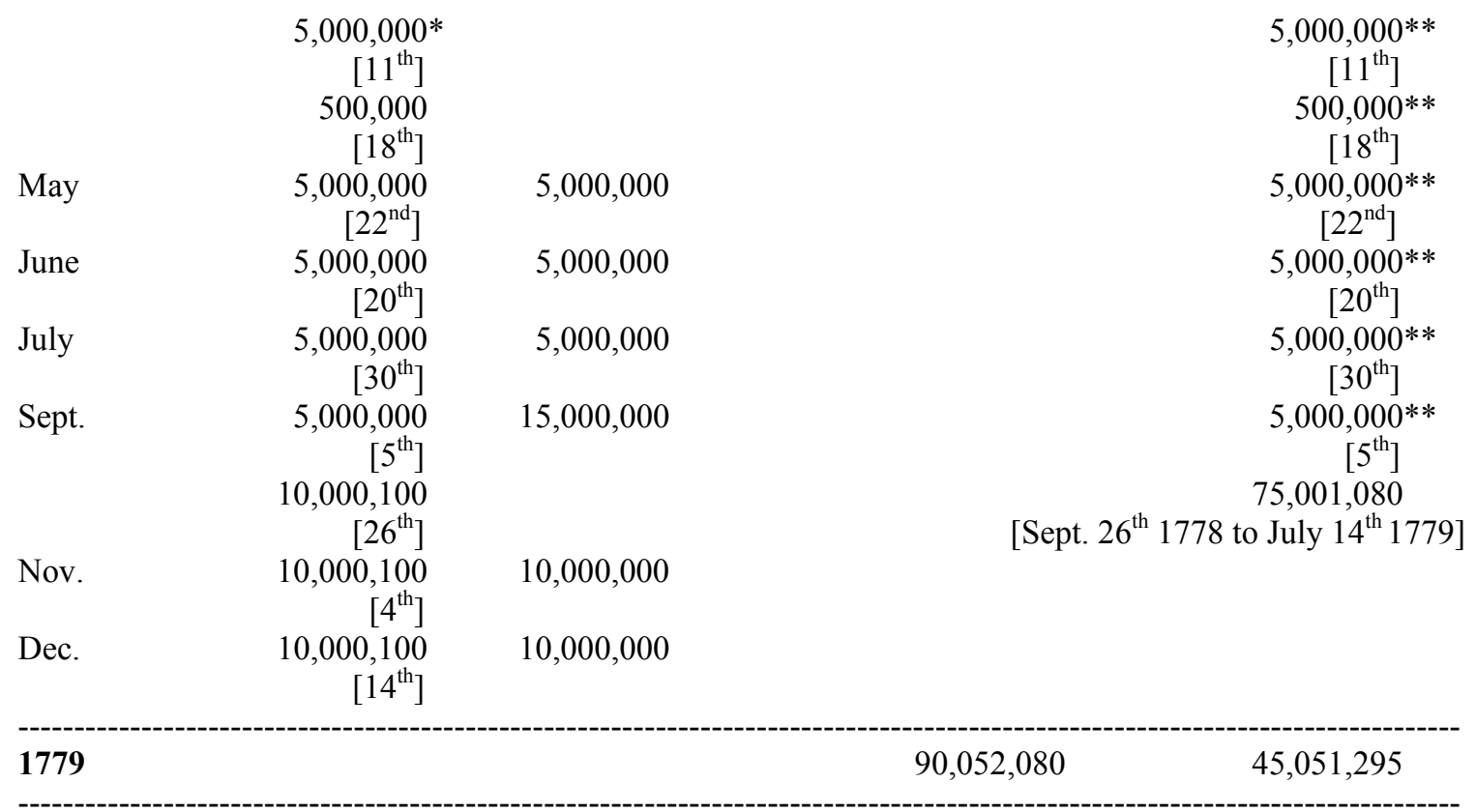

Adjustment Guess Made for Jan. $14^{\text {th }}$ 1779:

In addition, on Jan. $14^{\text {th }}$ Congress voted $\$ 50,000,400$ to be exchanged for issues since May $20^{\text {th }} 1777$ that were being counterfeited. How much was actually exchanged and how much was a net new emission is unknown. ${ }^{*}=$ emissions exchanged as interpreted by Bullock. ** = emissions exchanged as implied by Newman. ${ }^{\wedge}=$ the exchanged sum chosen by Elliot such that "C. Discrepancy $[\mathbf{A}-\mathbf{B}]$ " below equals zero.

\begin{tabular}{|c|c|c|c|c|}
\hline net new & $\begin{aligned} & {[50,000,400} \\
- & \left.25,552,780^{\wedge}\right] \\
= & 24,447,620\end{aligned}$ & $\begin{array}{l}{[50,000,000} \\
-10,000,000 *] \\
=40,000,000\end{array}$ & $\begin{array}{lr}\text { Harlow } & =0 \\
\text { Michener }=50,000,000\end{array}$ & $\begin{array}{l}{[50,000,400} \\
\left.-36,500,000^{* *}\right] \\
=13,500,400\end{array}$ \\
\hline Feb. & $\begin{array}{r}5,000,160 \\
{\left[3^{\text {rd }}\right]} \\
5,000,160 \\
{\left[12^{\text {th }}\right]}\end{array}$ & $10,000,000$ & & \\
\hline Apr. & $\begin{array}{r}5,000,160 \\
{\left[2^{\text {nd }}\right]}\end{array}$ & $5,000,000$ & & \\
\hline May & $\begin{array}{r}10,000,100 \\
{\left[5^{\text {th }}\right]}\end{array}$ & $10,000,000$ & & \\
\hline June & $\begin{array}{r}10,000,100 \\
{\left[4^{\text {th }}\right]}\end{array}$ & $10,000,000$ & & \\
\hline July & $\begin{array}{r}15,000,280 \\
{\left[17^{\text {th }}\right]}\end{array}$ & $15,000,000$ & & \\
\hline
\end{tabular}

\section{Comparison Interlude:}

A. Totals so far- to Sept. 2, 1779:

$$
\begin{aligned}
& \text { Harlow } \quad 151,501,260^{\mathrm{a}} \\
& 159,948,880^{\wedge} \quad 191,500,000 \quad \text { Michener } 201,448,480^{\mathrm{a}} \quad 165,001,600^{\mathrm{a}}
\end{aligned}
$$

B. Total Congress Declared as in Circulation on Sept. 2, 1779 (Bullock, 1895, p. 136; Elliot, 1843-44, p. 8):

$$
159,948,880 \quad 159,948,880 \quad 159,948,880 \quad 159,948,880
$$




\begin{tabular}{lrr} 
C. Discrepancy $[\mathbf{A}-\mathbf{B}]=$ & \\
\cline { 2 - 2 } & & \\
& & \\
Sept. & $15,000,260$ & $15,551,120$ \\
& {$\left[17^{\text {th }}\right]$} & \\
Oct. & $5,000,180$ & $5,000,000$ \\
& {$\left[14^{\text {th }}\right]$} & \\
Nov. & $10,050,540$ & $20,050,000$ \\
& {$\left[17^{\text {th }}\right]$} & \\
& $10,000,140$ & \\
& {$\left[29^{\text {th }}\right]$}
\end{tabular}

Harlow $\quad-8,447,620$

Michener $+41,499,600 \quad+5,052,780$

None thereafter

\begin{tabular}{|c|c|c|c|c|c|}
\hline $\begin{array}{l}\text { Totals Implied } \\
\text { Or Reported } \\
\text { 1775-1780 } \\
\text { Corrected for Ac }\end{array}$ & $\begin{array}{l}\text { dition and Omi } \\
+16,000,000^{b}\end{array}$ & $\begin{array}{l}\text { on Errors: } \\
-9,950,000^{c}\end{array}$ & $\begin{array}{l}\text { Harlow } \\
\text { Michener }\end{array}$ & $\begin{array}{l}191,552,380 \\
241,500,000\end{array}$ & $205,052,775$ \\
\hline \multicolumn{6}{|c|}{ And Then Corrected or Re-corrected such that "C. Discrepancy $[\mathbf{A}-\mathbf{B}]$ " = zero: } \\
\hline & $-16,000,000$ & $-31,551,120$ & $\begin{array}{l}\text { Harlow } \\
\text { Michener }\end{array}$ & $\begin{array}{r}+8,447,620 \\
-41,499,600\end{array}$ & $-5,052,780$ \\
\hline \multicolumn{6}{|c|}{ Final Corrected Total Amount Outstanding in 1780: ${ }^{\mathrm{d}}$} \\
\hline & $200,000,000$ & $199,998,880$ & $\begin{array}{l}\text { Harlow } \\
\text { Michener }\end{array}$ & $\begin{array}{l}200,000,000 \\
200,000,400\end{array}$ & $199,999,995$ \\
\hline
\end{tabular}

Notes and Sources: Bullock (1895, pp. 135-136); Calomiris (1988, pp. 57-58); Elliot (1843-44, p. 8);

Harlow (1929, pp. 50-51); Michener (1988, p. 690); Newman (1997, pp. 58-69).

a Because Elliot's numbers for 1779 and for Sept. $26^{\text {th }} 1778$ through Nov. $29^{\text {th }} 1779$ sum to the same total as those for Harlow and Michener, and those for Newman, respectively, the values reported by Elliot were used to apportion Harlow and Michener's, and apportion Newman's, numbers for 1779 into before versus after Sept. 2, 1779, respectively.

b Elliot omitted these sums between 1775 and early 1777, designated as "?" in the table.

' Bullock's individual sums $(231,550,000)$ simply do not add up to what he reports as the total $(241,500,000)$. Calomiris did not correct this addition error when using Bullock’s numbers.

${ }^{\mathrm{d}}$ As such, the Jan. $14^{\text {th }} 1779$ adjustment is made uniform across estimates such that $[50,000,000-$ $41,552,380$ (exchanged)] $=8,447,620$ of net new emission. The remaining differences are due to rounding. 
This correction made to Bullock's estimate solves the anomaly that Bullock himself puzzled over (Bullock, 1895 , p. 136). This estimate also accords with Ferguson (1961, p. 45) who claims that $\$ 41,500,000$ was exchanged out of the $\$ 50,000,400$ authorized for exchange which would then potentially leave $\$ 8,500,400$ as a net new emission. This estimate also accords with the limit set by Congress on September 3, 1779 of a maximum of $\$ 200,000,000$ Continental Dollars that could be emitted before emissions were permanently discontinued (Ferguson, 1961, p. 46). 
Table A2. Continental Dollars (Old Emission 1775-1779) Paid by each State from 1780 through 1790 as Part of Their Tax Revenues due the National Government into the U.S. Treasury that was Examined, Counted, and then Burnt by the U.S. Treasury (Face Value in Nominal Dollars)

\begin{tabular}{|c|c|c|c|}
\hline Year & Month Day & Amount & State Sending Payment \\
\hline 1780 & $\begin{array}{l}\text { Nov. } 25 \\
\text { Nov. } 25 \\
\text { Dec. } 23\end{array}$ & $\begin{array}{r}\$ 949,430 \\
115,117 \\
237,840\end{array}$ & $\begin{array}{l}\text { New Jersey } \\
\text { Maryland } \\
\text { New Jersey }\end{array}$ \\
\hline 1781 & $\begin{array}{l}\text { Jan. } 1 \\
\text { Feb. } 13 \\
\text { Mar. } 23 \\
\text { Apr. } 3 \\
\text { Apr. } 17 \\
\text { May } 15 \\
\text { May } 29 \\
\text { May } 30 \\
\text { June } 11 \\
\text { June } 11 \\
\text { Aug. } 2 \\
\text { Aug. } 4 \\
\text { Oct. } 6 \\
\text { Nov. } 6\end{array}$ & $\begin{array}{r}599,396 \\
1,400,527 \\
631,523 \\
2,599,987 \\
802,717 \\
1,999,995 \\
5,785,555 \\
712,824 \\
2,299,769 \\
12,984,001 \\
1,456,417 \\
4,402,413 \\
1,139,181 \\
16,876,618\end{array}$ & $\begin{array}{l}\text { New York } \\
\text { Pennsylvania } \\
\text { New Jersey } \\
\text { Pennsylvania } \\
\text { Virginia } \\
\text { Pennsylvania } \\
\text { Virginia } \\
\text { New Jersey } \\
\text { New Hampshire } \\
\text { Massachusetts } \\
\text { New Jersey } \\
\text { Pennsylvania } \\
\text { New Jersey } \\
\text { Massachusetts }\end{array}$ \\
\hline 1782 & $\begin{array}{l}\text { Jan. } 7 \\
\text { Jan. } 30 \\
\text { Feb. } 23 \\
\text { May } 30 \\
\text { June } 3 \\
\text { July } 30 \\
\text { Aug. } 7 \\
\text { Aug. } 31 \\
\text { Sept. } 18 \\
\text { Nov. } 22 \\
\text { Dec. } 6 \\
\text { Dec. } 19\end{array}$ & $\begin{array}{r}2,210,000 \\
1,373,811 \\
1,207,111 \\
3,367,670 \\
2,805,318 \\
5,009,343 \\
1,599,758 \\
387 \\
2,900,231 \\
2,954,918 \\
1,000,391 \\
77,623\end{array}$ & $\begin{array}{l}\text { Delaware } \\
\text { New York } \\
\text { New Jersey } \\
\text { Pennsylvania } \\
\text { Pennsylvania } \\
\text { Pennsylvania } \\
\text { Pennsylvania } \\
\text { Massachusetts } \\
\text { New Hampshire } \\
\text { Pennsylvania } \\
\text { Pennsylvania } \\
\text { Pennsylvania }\end{array}$ \\
\hline 1783 & $\begin{array}{l}\text { Jan. } 20 \\
\text { Jan. } 29 \\
\text { Feb. } 21\end{array}$ & $\begin{array}{r}47,535 \\
331,369 \\
392,833\end{array}$ & $\begin{array}{l}\text { Pennsylvania } \\
\text { Pennsylvania } \\
\text { New Jersey }\end{array}$ \\
\hline
\end{tabular}

Aug. 2

Aug. 22

2,151,478 New York

Aug. 22

430,969 Maryland

473,779 Maryland

151,417 Maryland

Sept. 12

26,650 Maryland

Sept. 16

132,929 Maryland

Sept. 16

2,880,720 Virginia 
Nov. 1

Nov. 9

Dec. 7

Dec. 13

Dec. 29

1787 Jan. 22

July 5

Aug. 13

Aug. 17

Nov. 13

1788 Mar. 28

Aug. 25

Sept. 5

1789 Mar. 18
$1,523,224 \quad$ Virginia

$62,481 \quad$ Maryland

$8,102,425$ Connecticut

40,072 Maryland

21,750 Maryland

89,905 Maryland

2,048,160 Virginia

2,593,353 Rhode Island

99,516 New Jersey

857,827 Pennsylvania

172,677 New York

$1,049,060$ Connecticut

6,780,026 Maryland

5,066,861 North Carolina

Total $\$ 119,462,370$

Notes and Sources: Derived from Elliot (1843-44, pp. 73-76) "Schedule E. Statement of the sums, in the old continental emissions, paid by the following States into the treasury of the United States, on account of their several quotas of the requisitions of Congress, of March 18, 1780." No payments by South Carolina and Georgia are recorded which is consistent with the other U.S. Treasury records on the payments by the various state in different mediums of exchange, see Elliot (1843-44, pp. 68-69). No payments are recorded as being received for years 1784 and 1785 . 


\section{Footnotes}

${ }^{1}$ William Bingham, a director of the Bank of North America, to Alexander Hamilton, U.S. Treasury Secretary, November 25, 1789. (Syrett, 1962, v. 5, p. 554)

${ }^{2}$ The literature typically refers to "un-defaulted" debt as restructured, redeemed, paidoff, or reassumed debt. The term un-defaulted is used here in place of these other terms because I feel it more accurately and starkly captures what was being considered at this time as applied both to the interest-bearing and the non-interest-bearing debt in the U.S.

${ }^{3}$ As a sovereign entity the U.S. National Government could not be forced to liquidate its assets to pay off its debts when in default like a private business. Nevertheless, default is costly to sovereign entities in terms of lost reputation, credit rating, and access to borrowing in the future - a cost that the potential sale of capital assets could avert.

${ }^{4}$ Debt liabilities (D) include both interest-bearing bonds (B) and non-interest-bearing bills of credit, or fiat paper money $(\mathbf{M})$, i.e. $\mathbf{D}=\mathbf{B}+\mathbf{M}$. The National Government did not issue new M after 1779 and the new U.S. Constitution, by convention vote in 1787, prohibited the Federal Government from issuing new M thereafter (Farrand, 1996, v. 2, pp. 308-310; Grubb 2006). As such, only the B portion of D factors into G. Paying down or retiring any of the face value of the principal, either of $\mathbf{B}$ or $\mathbf{M}$, without liquidating assets, however, would still require a current-year budget surplus $(\mathbf{T}-\mathbf{G}>0)$. As such, distinguishing between $\mathbf{B}$ and $\mathbf{M}$ in the model is not necessary, except with regard to whether the mass of $\mathbf{M}$ issued prior to 1780 that was still outstanding in this era as part of D could potentially be retired by the National Government at face value.

5 On the government's chronic budget deficits, see Taylor (1950, p. 5); on Shay’s Rebellion, see Richards (2002) and Szatmary (1980); on the Whiskey Rebellion, see 
Bouton (1996), Tindall (1988, pp. 320-321), Syrett (1972, v. 17, pp. 2-6, 9-58, 61-72, 7778); and on Fries' Rebellion, see Tindall (1988, pp. 333-334). All three rebellions were tax revolts that involved calling out the regular army on a substantial scale to confront its own citizens. The Whiskey Rebellion witnessed the only time a sitting U.S. President as commander-in-chief has taken the field at the head of an army. The Founding Fathers were aware that public resistance was a constraint on raising new taxes. In late 1789 James Madison, congressman from Virginia, wrote to Alexander Hamilton, the Secretary of the Treasury, that, "In my opinion, in considering plans for the increase of our revenue, the difficulty lies, not so much in the want of objects as in the prejudices which may be feared with regard to almost every object. The Question is very much What further taxes will be least unpopular?" (Syrett, 1962, v. 5, p. 439) Hamilton may have doubted the government's ability to raise enough revenue to meet expenses. In late 1789 as Secretary of the Treasury he broached the possibility of quietly approaching the French to see "...if the installments of the Principal of the debt [the U.S. owed France] could be suspended for a few years, [as] it would be a valuable accommodation to the U.S.” (Syrett, 1962, v. 5, pp. 426, 429) Letters between Hamilton, as Secretary of the Treasury overseeing the tariff revenue tax, and his port agents often alluded to the problem of smuggling, the difficulty of enforcing the tariff, and the difficulty of collecting tariff revenues. As one customs officer put it in late 1789, "The difficulties that have occurred in the Execution of the laws respecting the Customs have been infinite, and present themselves daily. The System itself is the most complicated and embarrassing of anything that has employed my attention...[and] the Owners pay with reluctance...others not at all without compulsion; and the law provides none." (Syrett, 
1962, v. 5, pp. 422, 427, 459-464; 1972, v. 17, pp. 6-7) Hamilton expected revenue shortfalls from the tariff as he suggested new taxes, such as the Whiskey Tax, in his December 13, 1790 "First Report on the Further Provision Necessary for Establishing Public Credit" sparking the 1794 rebellion (Tindall, 1988, pp. 301, 320; Syrett, 1963, v. 7, pp. 225-236). Finally, the yearly value of imports (the principal revenue source of government via the tariff) fluctuated greatly during this period making tariff revenues uncertain, see North (1966, pp. 19-32, 228). Regarding problems with trade treaties in this period, see Tindall (1988, pp. 316-318, 330-331); Madison in 1786 on “...the present anarchy of our commerce..."(Rutland, 1973, v. 8, pp. 502-503); and Hamilton's 1794 letter to President George Washington (Syrett, 1972, v. 16, pp. 261-279).

${ }^{6}$ Interestingly, Tench Cox, in a pamphlet circulated at the Constitutional Convention [1787], observed that "The general impost...the sale of the lands and every other unnecessary article of public property ... would put the sinking and funding of our debts within the power of all the states.” (Syrett, 1962, v. 5, p. 63-italics added)

${ }^{7}$ Talleyrand, in his statement quoted above touting the safety of U.S. bonds, refers to the "solvency" of the U.S. National Government. It is hard to interpret "solvency" here as meaning anything other than a positive net asset position, with land being the principal asset. In the 1790s Talleyrand himself had flirted with speculation in U.S. western lands.

${ }^{8}$ For more on the land to debt linkage, see Robbins (1942, p. 15); Taylor (1950, p. 40); Syrett (1962, v. 5, p. 526); and the United States Congress, Register of Debates in Congress (House of Representatives), v. 1, pp. 647-654 (July 13, 1789); v. 2, pp. 13451347 (February 22, 1790); v. 4, p. 1314 (December 15, 1794), pp. 1017-1018 (December 23, 1794); and v. 5, p. 60 (February 18, 1829). Gates concluded (1968, p. 56), "The 
transfer of these territories probably did more than anything else at the time to give prestige to the government." Finally, even by 1832 congressmen still referred to the requirement of applying the proceeds from the sale of public lands first to payments on the National Debt and only after the National Debt was paid off could they use the proceeds for some other use (United States Congress, Register of Debates in Congress, v. 5, p. 1452 (December 27, 1832); v. 5, pp. 1475-1478 (January 4, 1832)).

${ }^{9}$ For example, Ferguson's explanation of this differential treatment is that the interestbearing debt was held in high esteem and the non-interest-bearing debt was held in low esteem (1961, pp. 67-69, 295-297)—which is a vacuous explanation.

${ }^{10}$ Hamilton estimated the total Federal Debt (state and national) to be $\$ 77,124,465$ for 1789/1790 (Taylor, 1950, p. 1; Syrett, 1962, v. 6, pp. 85-87). In this number Hamilton included \$2 million Continental Dollars. He did not say why he included it or how he calculated it. Perhaps this was his anticipated value of the outstanding Continental Dollars at his proposed continuation of the 40 to 1 default rate that had been used by Congress since March 18, 1780 (\$80,537,630 million Continental Dollars outstanding in 1789 - see Table 1 — converts to $\$ 2,013,441$ million when using the 40 to 1 default rate). This explanation is consistent with the $\$ 80.5$ million estimate here of the amount of Continental Dollars still outstanding in 1789. Hamilton, as Secretary of the Treasury, would have had all the same treasury evidence as that presented here in the Appendices and so could have made the same calculation. If Hamilton was not simply dividing $\$ 80$ million Continental Dollars by 40 to get $\$ 2$ million Continental Dollars in defaulted value, then his $\$ 2$ million statement is a mysterious curiosity. (If he really meant that only \$2 million Continental Dollars in face value were still outstanding at the time, then his 
proposed default on the Continental Dollar was an unnecessary and financially reckless act.) As such, the analysis here indicates that Hamilton, in his 1790 "Report on Public Credit," while proposing to un-default the interest-bearing debt was also in effect proposing to not un-default the Continental Dollar. Subtracting out this $\$ 2$ million of Continental Dollars leaves Hamilton at $\$ 75$ million in 1789/1790 for the interest-bearing debt alone, which is not far off the $\$ 72.3$ to $\$ 74.7$ million estimated here in Table 1 .

${ }^{11}$ This value also concurs with that of Ratchford (1941, p. 37) and with Congress' limit set on September 3, 1779 of a maximum of $\$ 200,000,000$ Continental Dollars that could be emitted before emissions were permanently discontinued (Ferguson, 1961, p. 46).

${ }^{12}$ Ferguson (1961, p. 67) says in regard to the mass of Continental Dollars issued and outstanding prior to the 1790 default affirmation act, "Eventually the dead mass of currency was drawn in by the states. A good part of it was scattered or destroyed, and in 1790 only about $\$ 6,000,000$ remained in the hands of individuals." Ferguson's source for his $\$ 6$ million number is Elliot (1843-44, p. 12). As such, Ferguson clearly misinterprets his source here. The $\$ 6$ million was the number estimated to have been actually exchanged at the 100 to 1 default rate for bonds after 1790 , not the amount outstanding at this date, which was estimated to be $\$ 78$ to $\$ 80$ million in the same source.

${ }^{13}$ Hamilton's plan to extinguish the principal of the interest-bearing debt was to devise a small sinking fund from any unexpected excess tariff revenue that would be used to buy up Federal debt in the marketplace when it traded at below face value. Given that the debt plan entailed forcing a small portion of debt holders to exchange their debt for new debt that carried a below-market interest rate, and given that Federal debt in general was being turned into callable perpetuities, these below-market interest rate bonds would trade at 
below face value. In effect, Hamilton was repudiating some of the interest-bearing debt and setting in motion a scheme to pay only the market rate for that debt. See Swanson and Trout (1992); Syrett (1962, v. 6, pp. 51-168); Taylor (1950, pp. 4-7). This observation and line of reasoning turns the monetary rhetoric of the early Republic on its head. Hamilton and the Federalists had argued that the debt had to be funded at face value and not market value. But in fact the sinking fund scheme did the opposite.

${ }^{14}$ This is a naïve version of the quantity theory of money in that Hamilton asserts strict proportionality between money growth and price inflation and he does not grasp the Fisher equation, i.e. that the nominal interest rate must equal the real rate plus inflation. Hamilton claims in his report that pumping money into the economy will permanently drive up prices and drive down nominal interest rates (Syrett, 1962, v. 6, pp. 71, 88-89).

${ }^{15}$ In the context of Hamilton's address he clearly is means the specie price of land. Thus Hamilton's fall in prices since the revolution of 25 to 50 percent refers to the fall in specie prices. Price indices in this period, 1783-1789, were denominated in state paper monies. Between 1783 and 1789 the Philadelphia price index fell only 18 percent, the Charleston, South Carolina price index fell only 20 percent, and the New York City price index fell only about 6 percent (Bezanson, 1936, p. 392; Cole, 1938, pp, 121-122, 156). Prices denominated in specie falling faster than prices denominated in state paper money, as Hamilton's statement implies, is consist with foreign trade disruptions in this period generating a sharp temporary shortfall in specie inflows. Thus, state paper money could be appreciating in goods (price deflation) but depreciating in terms of how much specie it could command (acute specie scarcity driving specie prices of goods down faster than the decline in the state-paper-money price of goods). The economic problem facing Hamilton 
and the Founding Fathers in the mid-1780s was not inflation or state paper money per se but foreign trade shocks reducing specie money supplies (Grubb, 2006; Nettels, 1962, 4546, 105). See also the assessments of James Wilson in 1785 (Adams, 1930, p. 145) and James Madison in 1786 (Rutland, 1973, v. 8, pp. 502-503).

${ }^{16}$ In 1791 the face value of the Federal interest-bearing debt totaled $\$ 77$ million. About $\$ 12$ million was foreign debt leaving $\$ 65$ million in the domestic economy (see Table 1). By Hamilton's own estimate in 1790 this debt traded at about 20 cents on the dollar of face value (Syrett, 1962, v. 6, p. 91). Thus, given that Hamilton's plan would re-inflate this debt to face value, the resulting amount of new cash so injected into the domestic economy would be [ $\$ 77$ million minus $\$ 12$ million] $* 0.8=\$ 52$ million.

${ }^{17}$ Hamilton also argued that the effect on prices would not be immediate or instantaneous. Some lag would intervene. In the January 1790 "Report on Public Credit" Hamilton wrote, "It ought not however to be expected, that the advantages, described as likely to result from funding the public debt, would be instantaneous. It might require some time to bring the value of stock to its natural level, and to attach to it that fixed confidence, which is necessary to its quality as money." (Syrett, 1962, v. 6, p. 72)

${ }^{18}$ See also Swanson and Trout (1992, pp. 428-429). Determining what Hamilton actually believed based on his words and logic is fraught with risk. Ratchford concluded that (1941, p. 52), "It is difficult, if not impossible, to determine the extent to which Hamilton really believed these things and the extent to which he used them because they fitted in with the ideas prevalent at the time, and thus were likely to meet with approval of legislators." Often Hamilton presented arguments for the position he wanted that appear designed primarily to win over different constituents - appearing to be as much 
political expediency as his own true belief. He would solicit opinions from others and then parrot back as many arguments as he needed to craft a winning coalition for his desired position (Syrett, 1962, v. 5; v. 6). For example, see the letter William Bingham, a director of the Bank of North America, sent to Hamilton on November 25, 1789 in which Bingham lays out many arguments that Hamilton puts in his January 1790 "Report on Public Credit” (Syrett, 1962, v. 5, pp. 538-554). In particular, Bingham wrote "The Scarcity of money had reduced even real Property $40 \%$ below its standard Value before the War..." and “...when the public Debt of a Country is well funded, which brings into the Market a Quantity of circulating Medium, readily transferable, \& which represents all the alienable Property of the Country, [it serves] almost as well as Specie..."

${ }^{19}$ By creating the First Bank of the U.S. in 1791 and then selling its shares in said bank, the National Government could also be considered to be able to create saleable assets for itself via creation of such corporations - no matter how constitutionally questionable such acts might have been. Such assets will be abstracted from here.

${ }^{20}$ Interestingly, he sale of the Chickasaw Trust Lands from 1836 through 1850 $(4,025,395$ acres for $\$ 3,326,404)$ yields an average nominal price of $\$ 0.83$ an acre which when deflation-adjusted back to 1785 would be approximately $\$ 1.00$ an acre (Gates, 1968, p. 186; Bezanson, 1936, p. 392).

${ }^{21}$ Part of the slowness of sale of the public domain early on may have been due to the several states that had retained significant western and northern lands outbidding the National Government for settlers by pricing their lands under that set by the National Government for the public domain (Gates, 1968, p. 128; Robbins, 1942, p. 9). 